\title{
SARS-CoV-2 mRNA vaccine elicits a potent adaptive immune response in the absence of IFN-mediated inflammation observed in COVID-19
}

Ellie N. Ivanova ${ }^{1 *}$, Joseph C. Devlin ${ }^{2,3^{*}}$, Terkild B. Buus ${ }^{1,4^{*}}$, Akiko Koide ${ }^{6,8}$, Jasmine Shwetar $^{2,3}$, Amber Cornelius $^{5}$, Marie I. Samanovic ${ }^{5,6}$, Alberto Herrera ${ }^{1}$, Eleni P. Mimitou ${ }^{11}$, Chenzhen Zhang $^{3}$, Ludovic Desvignes $^{5,9}$, Niels Odum ${ }^{4}$, Peter Smibert ${ }^{11}$, Robert J. Ulrich ${ }^{5,6}$, Mark J. Mulligan ${ }^{5}$, Shohei Koide $^{8,10}$, Kelly V. Ruggles ${ }^{2}$, Ramin S. Herati ${ }^{5,6 \#}$, Sergei B. Koralov ${ }^{1 \#}$

${ }^{1}$ Department of Pathology, NYU Grossman School of Medicine, New York, NY, 10016, USA.

${ }^{2}$ Institute of Systems Genetics, New York University Grossman School of Medicine, New York, NY 10016, USA

${ }^{3}$ Vilcek Institute of Graduate Biomedical Sciences, New York University Grossman School of Medicine, New York, NY 10016, USA.

${ }^{4}$ LEO Foundation Skin Immunology Research Center, Department of Immunology and Microbiology, University of Copenhagen, DK-2200 Copenhagen, Denmark

${ }^{5}$ New York University Langone Vaccine Center and New York University Grossman School of Medicine, New York, NY, 10016, USA.

${ }^{6}$ Department of Medicine, NYU Grossman School of Medicine, New York, NY, 10016, USA

${ }^{7}$ Department of Microbiology, NYU Grossman School of Medicine, 430 East 29th Street, New York, NY, 10016, USA.

${ }^{8}$ Perlmutter Cancer Center, NYU Langone Health, New York, NY, 10016, USA.

${ }^{9}$ Office of Science and Research, NYU Langone Health, New York, NY, 10016, USA.

${ }^{10}$ Department of Biochemistry and Molecular Pharmacology, New York University Grossman School of Medicine, New York, NY 10016, USA.

${ }^{11}$ New York Genome Center, New York, New York, USA

*Contributed equally to this work

\#Address correspondence: sergei.koralov@,nyulangone.org and ramin.herati@nyulangone.org 


\begin{abstract}
Both SARS-CoV-2 infection and vaccination elicit potent immune responses, but the durability and scope of immune responses remain to be elucidated. Here, we performed multimodal singlecell profiling of peripheral blood of patients with acute COVID-19 and healthy volunteers before and after receiving the SARS-CoV-2 BNT162b2 mRNA vaccine to compare the immune responses elicited by the virus and by the vaccine. Phenotypic and transcriptional profiling of immune cells, coupled with reconstruction of $\mathrm{B}$ and $\mathrm{T}$ cell receptor repertoires, enabled us to characterize and compare the host responses to the virus and to defined viral antigens. In COVID-19 patients, immune responses were characterized by a highly augmented interferon response which was largely absent in vaccine recipients. Increased interferon signaling likely contributed to the dramatic upregulation of cytotoxic genes in the peripheral $\mathrm{T}$ cells and innatelike lymphocytes observed in COVID-19 patients. Analysis of B and T cell repertoires revealed that while the majority of clonal lymphocytes in COVID-19 patients were effector cells, in vaccine recipients clonal expansion was primarily restricted to circulating memory cells. Taken together, our analysis of immune responses to the mRNA vaccine reveals that despite the lack of dramatic inflammation observed during infection, the vaccine elicits a robust adaptive immune response.
\end{abstract}

\title{
Introduction
}

In 2019, a novel coronavirus (SARS-CoV-2) emerged and the resulting pandemic has had unprecedented impact on the heath, economy, and social fabric of the global community. The clinical presentation of coronavirus disease 2019 (COVID-19), the disease caused by SARS$\mathrm{CoV}-2$, has been highly heterogeneous, with manifestations ranging from asymptomatic or mild illness, to acute respiratory distress syndrome (ARDS), multiorgan failure, and death.

To date, a number of comprehensive studies have described immune responses to SARS-CoV-2 infection (Desai et al., 2020; Mathew et al., 2020; Merad and Martin, 2020; Singh et al., 2020; Wilk et al., 2020; Zheng et al., 2021). These research efforts identified lymphopenia with concomitant innate cell expansion, while specific alterations in a number of immune subsets, including activated CD8 T cells, plasma cells, monocytes, and NK cells, are thought to shape the clinical outcomes of patients. Immune responses in individuals who survive COVID-19 eventually return to baseline, with establishment of memory $\mathrm{T}$ and B cell responses (Kared et al., 2021; Le Bert et al., 2020; Zhang et al., 2020; Zuo et al., 2021), and corresponding development of a neutralizing antibody repertoire (Jeewandara et al., 2021; Wang et al., 2020). Although memory responses to COVID-19 are evident in convalescent individuals, the longevity of immune memory to SARS-CoV-2 and molecular and cellular characteristics responsible for durability of these responses remain to be elucidated.

Infection with SARS-CoV-2 and vaccination against the virus have both been shown to stimulate immune responses and protect against subsequent infection (Cervia et al., 2021; Chodick et al., 2021; Dan et al., 2021; Lederer et al., 2020; Sherina et al., 2021; Thompson et al., 2021; Wu et al., 2021). SARS-CoV-2 contains four structural proteins, the envelope (E) and membrane (M) proteins, which insert into the viral envelope, the nucleocapsid (NC) protein, which binds the 
viral RNA, and the spike (S) glycoprotein, another viral envelope protein which binds to receptors on the host cell via the receptor-binding domain (RBD) (Satarker and Nampoothiri, 2020; Tai et al., 2020). In contrast, the BNT162b2 mRNA vaccine contains a lipid nanoparticleformulated nucleoside-modified mRNA that encodes the prefusion stabilized form of the $\mathrm{S}$ protein only (Bos et al., 2020; Hsieh et al., 2020; Vogel et al., 2020). Both infection and vaccination generate protective anti-S memory immune responses (Chodick et al., 2021; Dan et al., 2021; Thompson et al., 2021). However, the innate and adaptive immunity established by each is likely to be substantially qualitatively different from the other. Comparison of immune responses generated by the vaccine and the virus provides a unique opportunity to juxtapose antigen driven response to the profound inflammatory response associated with infection.

In our study, we took advantage of 5'-CITE-seq (5' Cellular Indexing of Transcriptomes and Epitopes by sequencing), a multimodal, single-cell sequencing technique, to simultaneously characterize the surface phenotype and transcriptome of immune cells (Mimitou et al., 2019; Stoeckius et al., 2017). This platform also enables reconstruction of B cell and T cell antigen receptor rearrangement of individual lymphocytes. We utilized the 5' -CITE-seq platform to characterize cellular and transcriptional responses to SARS-CoV-2 infection and vaccination in peripheral immune cells in an effort to better understand the host response to the pathogen and immunization against defined viral antigens. We also used a recently developed multiplex beadbinding assay to quantify virus-specific antibody titers in the serum of COVID-19 patients and vaccine recipients.

Our multimodal analysis revealed dramatic alterations in the frequencies and transcriptional programs of several immune subsets in response to infection and highlighted differences in the breadth of immune response observed upon infection and vaccination. In COVID-19 patients, transcriptional profiles of many immune populations were characterized by augmented interferon (IFN) signaling, upregulation of genes associated with cytotoxicity, and changes in metabolic pathways. Analysis of peripheral immune cells following vaccination with the SARS-CoV-2 BNT162b2 mRNA vaccine revealed alterations of transcriptional programs of several immune populations consistent with immune activation, but the highly augmented IFN signaling and cytotoxic signature observed in COVID-19 patients were largely absent. We observed robust antibody response in both COVID-19 patients and immunized individuals, with vaccination inducing a remarkably consistent $\mathrm{IgG}$ and $\mathrm{IgA}$ response to $\mathrm{S}$ protein. Interestingly, the nature of clonal $\mathrm{B}$ and $\mathrm{T}$ cell responses differed dramatically between infected and vaccinated individuals, suggesting that inflammatory responses associated with infection influence the trajectory of the adaptive immune response - differences that may have important implications for our understanding of durability of protective immune responses.

\section{Results}

\section{Overview of immune responses to COVID-19 infection and immunization}

To improve our understanding of immune responses to SARS-CoV-2 antigens in different inflammatory contexts we profiled circulating immune cells from five adults with acute COVID- 
19 and five healthy adults, three of whom received the SARS-CoV-2 BNT162b2 mRNA vaccine, and two who were SARS-CoV-2 naïve. Samples were taken at multiple time points resulting in a total of 30 samples (Schematic 1). Three individuals were sampled during the acute phase of infection and two in later stage of disease, with longitudinal samples collected from four of the five patients. Time points were recorded as days post-onset (DPO) of symptoms, and clinical metadata were evaluated for clinical severity based on the WHO clinical progression scale (WHO Working Group on the Clinical Characterisation and Management of COVID-19 infection, 2020). All subjects in the vaccine group received two doses of the vaccine approximately three weeks apart, in accordance with its FDA Emergency Use Authorization. For vaccine responses, samples were collected at baseline, and then at approximately 1, 2, 3, 4, 5, and 7 weeks after the first vaccine dose. For all participants, demographic characteristics, clinical features, and outcomes are listed in Supplemental Table 1.

To assess the impact of SARS-CoV-2 infection and vaccination on the individuals' global immune landscape, we utilized multimodal 5'-CITE-seq approach (Mimitou et al., 2019) to identify discrete clusters based on transcriptional profile and surface epitopes of circulating cells. To do this, peripheral blood mononuclear cells (PBMCs) were multiplexed and processed using 5 ' droplet-based scRNA-seq technology (10x Genomics). Surface marker phenotypes were detected using an optimized 60 antibody CITE-seq panel (Buus et al., 2020), generating matching transcriptional and surface protein data. In addition, single-cell $\mathrm{T}$ cell receptor (TCR) $\alpha \beta$ and $\gamma \delta$, as well as B cell receptor (BCR), sequencing was performed for each sample to evaluate antigen receptor repertoires. Samples from healthy volunteers prior to vaccination with BNT162b2 were grouped together with samples from unvaccinated COVID-19-naïve healthy donors as healthy controls (HC).

In total, 123,272 PBMCs from 27 individual samples were obtained, with an average of 4,500 cells/sample. Among these, 36,971 cells ( 30\%) were from COVID-19 patients, 26,228 cells $(\sim 22 \%)$ from HCs and pre-vaccine samples, and 60,073 cells $(\sim 49 \%)$ were from postimmunization samples. All high-quality single cells were integrated across the RNA, antibodyderived tags (ADTs), TCR and BCR modalities for all subsequent analyses. Dimension reduction was performed utilizing the combined RNA and ADT modalities to generate a uniform manifold approximation and projection (UMAP) (McInnes and Healy, 2018) representation of all 123,272 cells from HC, immunized volunteer and COVID-19 patient samples (Figs. 1A,B). Using a combination of Louvain-based clustering (Blondel et al., 2008), SingleR(Aran et al., 2019) reference-based annotation, and literature markers we identified 9 major lineages (Fig. 1A and Supplemental Fig. 1A) and 32 individual subpopulations of myeloid cells, B cells, conventional and innate-like T cells, and NK cells (Figs. 1C-F). Gene expression and canonical ADT markers further confirmed these lineages and sub-populations (Supplemental Fig. 1A).

A number of studies have revealed a highly heterogenous picture of the anti-viral inflammatory responses in COVID-19 patients, likely due to variability of disease severity, stage of disease, and diversity of preexisting conditions (Desai et al., 2020; Mathew et al., 2020; Merad and Martin, 2020; Singh et al., 2020; Wilk et al., 2020; Zheng et al., 2021). However, our analysis revealed striking differences in the frequency of key immune populations between COVID-19 patients and healthy volunteers prior to and following vaccination (Fig. 1G,H, Supplemental Fig. 1B-D). 
medRxiv preprint doi: https://doi.org/10.1101/2021.04.20.21255677; this version posted August 23, 2021. The copyright holder for this preprint (which was not certified by peer review) is the author/funder, who has granted medRxiv a license to display the preprint in perpetuity. All rights reserved. No reuse allowed without permission.

\section{Myeloid cells are a likely source of type I interferon during SARS-CoV-2 infection}

Myeloid cells with high expression of Toll-like receptors (TLR) and other pattern-recognition receptors are likely the first to respond to viral infection. Robust induction of type I IFN through the activation of TLRs constitutes a critical aspect of antiviral immunity. IFN production is dependent on transcription factors IRF7 and IRF8, which interact with MyD88 (Lester and Li, 2014; Tailor et al., 2007; Xagorari and Chlichlia, 2008). Prior studies of immune responses during COVID-19 found increased activity of these innate immune pathways (Scagnolari et al., 2021; Xu et al., 2020; Zhou et al., 2020). When we assessed expression of genes associated with IFN production, including IRF7, IRF8, and MyD88 in myeloid cells, plasmacytoid DCs (pDCs) from COVID-19 patients stood out as having high level of expression of these genes (Fig. 2A). Differential gene expression analysis of pDCs from COVID-19 patients and immunized individuals revealed a dramatic upregulation of gene signature associated with type I and type II IFN production in the former and not the latter (Fig 2B). Despite heterogeneity in innate immune responses, M1 macrophages among COVID-19 patients were also notable for their marked increase in expression of genes associated with virus-induced IFN production, especially at early time points (Supplemental Fig. 2A,B). The observed expansion and transcriptional signatures of these populations in COVID-19 patients are consistent with the central role of IFN signaling in anti-viral immunity and in shaping downstream adaptive immune responses.

\section{Dramatic difference in maturation of B cell responses triggered by SARS-CoV-2 infection and vaccination}

Current COVID-19 vaccine efforts have focused on generation of humoral immune responses against SARS-CoV-2, which was demonstrated to be a correlate of protection against infection (McMahan et al., 2021). The primary target of neutralizing antibodies is the RBD of the S protein (Premkumar et al., 2020; Tai et al., 2020). To evaluate antibody responses following COVID-19 infection and immunization, we utilized a Multiplex Bead Binding Assay (MBBA), which permits flow cytometry-based profiling of serum antibodies against multiple viral epitopes (Hattori et al., 2021). In this assay, we quantified serum IgG, IgA, and IgM antibodies specific to three viral epitopes: S1 domain of spike, RBD, and NC (Fig. 3A, Supplemental Figs. 3A-C). As expected, anti-NC antibodies were only detected in COVID-19 patients, but not in healthy adults who received the BNT162b2 mRNA vaccine, which encodes only the S protein of SARS-CoV-2 (Supplemental Fig. 3A).

Serums antibody titers were highly variable in COVID-19 patient samples (Fig. 3A, Supplemental Figs. 3A-C), consistent with previous findings (Noval et al., 2021). Overall, IgG, IgA, and IgM antibody titers against all viral antigens were higher in late and convalescent samples in all participants for whom longitudinal data were available, except SK-010. In this individual, IgG, IgA, and IgM antibodies against all viral antigens assayed decreased in convalescent samples relative to earlier time points.

Unlike the heterogenous humoral responses in COVID-19 patients, all volunteers who received the vaccine mounted robust $\mathrm{IgG}, \mathrm{IgA}$, and $\operatorname{IgM}$ antibody responses against $\mathrm{S} 1$ and $\mathrm{RBD}$, with 
medRxiv preprint doi: https://doi.org/10.1101/2021.04.20.21255677; this version posted August 23, 2021. The copyright holder for this preprint (which was not certified by peer review) is the author/funder, who has granted medRxiv a license to display the preprint in perpetuity. All rights reserved. No reuse allowed without permission.

serum antibody titers comparable to those seen in COVID-19 patients (Fig. 3A, Supplemental Figs. 3A-C). These responses were evident two weeks after the first vaccine dose and peaked one week after the second dose, consistent with previous reports (Ebinger et al., 2021). IgG antibody levels remained high for at least seven weeks following the first vaccine dose, whereas IgA antibody titers declined steadily beginning one week after the second vaccine dose, although they remained elevated relative to baseline measurements.

To better understand the humoral responses following infection and vaccination, we examined B cell responses in the CITE-seq dataset. Single-cell analysis identified five distinct B cell populations based on gene expression and surface epitopes (Fig. 1D). We observed striking expansion of circulating plasmablasts in COVID-19 patients at both early and late time points relative to healthy volunteers (Fig. 1G). In contrast, there was no apparent expansion of plasmablasts in circulation following vaccination, despite the clear evidence of a successful humoral response in all subjects (Fig. 3A).

As plasmablasts are likely recent emigrants from lymphoid tissue (Vella et al., 2019), we hypothesized that they may carry a transcriptional imprint of the inflammatory milieu in tissue. We performed Gene Set Variation Analysis (GSVA) of plasmablasts from COVID-19 patients and healthy volunteers to ask whether signaling pathways were similarly expressed between these cohorts (Fig. 3B). This analysis revealed that plasmablasts from COVID-19 patients across all time points were highly enriched for genes involved in oxidative phosphorylation, type I and type II IFN responses, fatty acid metabolism, and mTORC1 signaling, relative to plasmablasts in healthy volunteers. Plasmablasts from both COVID-19 patients and healthy volunteers following vaccination were enriched for genes involved in IL-6 receptor signaling (JAK/STAT) and inflammatory response, which was consistent with the role of these pathways in promoting plasmablast differentiation (Hirano et al., 2000; Rodríguez-Bayona et al., 2013). Plasmablasts from immunized healthy volunteers were enriched for the transcriptional signature of TNF$\mathrm{NF \kappa B}$ pathway activation. Although signaling pathways among plasmablasts were overall similar in healthy adults and those undergoing vaccination, the increased IFN signaling seen in plasmablasts during acute COVID-19 suggested altered inflammatory milieu in infected patients. These transcriptional changes in response to IFN and other pro-inflammatory cytokines are likely to have broader implications for B cell differentiation and persistence.

The extent of upregulation of IFN response genes in COVID-19 patients correlated with severity of disease, as judged by fraction of inspired oxygen (Fig. 3C) and was consistent with elevated IFN production signature observed in pDCs from these patients. Furthermore, principal component analysis (PCA) of each sample based on the averaged single-cell plasma cell expression of interferon-stimulated (Liu et al., 2012) transcripts indicated vaccinated and HC samples clustered away from COVID-19 patient samples (Supplemental Fig. 3D). COVID-19 patient samples further separated along PC1 by disease severity and in correlation with expression of ISG20, LY6E, BST2 and STAT1 transcripts which are consistent with IFN-driven responses to viral infection (Kane et al., 2016; Liu et al., 2012) (Supplemental Fig. 3, Supplemental Table 1).

We next considered the B cell repertoire across these cohorts. Expansion of B cell clones, as well as convergent antibody repertoires have been reported for a number of viral infections, including 
medRxiv preprint doi: https://doi.org/10.1101/2021.04.20.21255677; this version posted August 23, 2021. The copyright holder for this preprint (which was not certified by peer review) is the author/funder, who has granted medRxiv a license to display the preprint in perpetuity. All rights reserved. No reuse allowed without permission.

SARS-CoV-2 (Gaebler et al., 2021; Jackson et al., 2014; Nielsen et al., 2020; Parameswaran et al., 2013; Robbiani et al., 2020). Analysis of BCR repertoire revealed that a majority of clonal B lineage cells were captured in the plasmablast cluster in COVID-19 patients. In vaccinated individuals, clonally expanded cells were primarily in resting and memory compartments (Fig. 3D). This observation suggests that the profound IFN response associated with SARS-CoV-2 infection may promote rapid plasma cell differentiation in COVID-19 patients, while the BNT162b2 mRNA vaccine appears to favor clonal expansion of memory B cells.

To evaluate extent of somatic hypermutation (SHM), we performed IgBlast (Ye et al., 2013) on the $\mathrm{V}_{\mathrm{H}}$ gene repertoire for each individual sample and then evaluated single base-pair mismatches in the full IgH repertoire of various B cell compartments. Increased SHM was apparent in memory B cells from all samples, with frequency of mutations notably higher when compared to naïve B cells from the same samples (Fig. 3E). Frequency of SHMs was significantly reduced in plasmablasts from convalescent COVID-19 samples compared to peak disease (Fig. 3E), possibly as a consequence of long-lived plasma cells migrating out of circulation. Although few plasmablasts were captured in PBMCs from vaccinated individuals, the rate of SHM in plasmablasts and memory B cells in these samples was comparable to that observed from COVID-19 patients at the peak of disease. There was an increase in SHM within the pool of memory cells one week after receiving the second dose of the vaccine compared to one week after receiving the first dose (Fig. 3E). Conspicuously, many of the most mutated variable $\left(\mathrm{V}_{\mathrm{H}}\right)$ genes in plasmablasts and memory B cells from COVID-19 patients and vaccinated individuals were from $\mathrm{V}_{\mathrm{H}}$ gene segments previously implicated in anti-SARS-CoV-2 responses (Brouwer et al., 2020; Gaebler et al., 2021; Mor et al., 2021; Robbiani et al., 2020; Wang et al., 2021; Zhang et al., 2021) (Fig. 3F). Taken together, these analyses highlight ongoing maturation of $\mathrm{B}$ cell responses in both COVID-19 patients and in vaccinated individuals.

Differences in SHM were suggestive of differences in germinal center (GC) biology between cohorts. Induction of effective high-affinity humoral immune responses and generation of memory B cells requires a specialized subset of CD4 Th cells known as T follicular helper (Tfh) cells. Tfh cells are essential for GC formation, affinity maturation, and the generation of most high-affinity antibody-producing and memory B cells (Crotty, 2019; Stebegg et al., 2018). A circulating population of Tfh cells, termed circulating Tfh (cTfh), are phenotypically and transcriptionally similar to lymphoid Tfh cells and their presence correlates with ongoing GC reaction and maturation of antibody response (Bentebibel et al., 2013; Herati et al., 2017; Vella et al., 2019). GSVA revealed that Tfh cells in in COVID-19 patients are enriched for genes involved in type I and type II IFN responses, which were notably absent in cTfh cells found in healthy volunteers (Supplemental Fig. 4). In contrast, cTfh cells from vaccinated individuals were enriched for the transcriptional signature of TNF-NFאB pathway activation, which has been shown to be associated with improved cTfh survival and robust humoral immune responses (Herati et al., 2019).

\section{NK and clonal $T$ cell responses differ in infection and vaccination}


medRxiv preprint doi: https://doi.org/10.1101/2021.04.20.21255677; this version posted August 23, 2021. The copyright holder for this preprint (which was not certified by peer review) is the author/funder, who has granted medRxiv a license to display the preprint in perpetuity. All rights reserved. No reuse allowed without permission.

Cell-mediated immune responses are carried out by NK cells, CD4 and CD8 T cells, and unconventional T lymphocytes like gamma delta $(\gamma \delta) \mathrm{T}$ cells. In COVID-19 patients, we observed dramatically elevated cytotoxic signature in NK cells, CD4 and CD8 T cells, and $\gamma \delta \mathrm{T}$ cells (Fig. 4A, Supplemental Fig. 5). While, consistent with prior reports of transient lymphopenia in COVID-19 (Chen and John Wherry, 2020; Cheng et al., 2019; Odak et al., 2020), we see an overall diminution of naïve CD8 T cells (Fig. 1H), we observed an increase in the frequency of proliferating $\mathrm{T}$ cells and NK cells in COVID-19 patents compared to healthy volunteers and vaccinated individuals (Fig. 4B,C). Both CD8 effector T cells and NK cells in COVID-19 patients showed significantly elevated expression of genes associated with cytotoxicity, such as GZMA, GZMB, GZMH, GNLY, NKG7, and PRF1 (Figs. 4C). This was consistent with previous findings that showed a dysregulation of immune responses in COVID19 (Kuri-Cervantes et al., 2020; Yu et al., 2020). Strikingly, while clonal expansion was readily evident only among the CD8 effector T cells in COVID-19 patient samples, the BNT162b2 vaccine elicited robust clonal responses in both $\mathrm{CD} 8$ effector $\mathrm{T}$ cells and in CD8/CD26 $\mathrm{T}_{\mathrm{EM}}$ cells, suggesting that the vaccine may be more potent at eliciting a memory CD8 response (Fig. 4D,E and Supplemental Figs. 6A,B).

While CD4 T cells generally help orchestrate and direct effectors of antiviral immune responses, they have also been implicated in direct elimination of infected cells through cytotoxic killing (Sun and Zhang, 2014; Swain et al., 2012; Takeuchi and Saito, 2017). Notably, activated CD4 T cells from COVID-19 patients expressed genes associated with cytotoxic effector function, such as GZMH, GZMA, and PRF1 (Supplemental Fig. 5). Cytotoxic CD4 T cells have been previously observed in COVID-19 and other viral infections (Juno et al., 2017; Meckiff et al., 2020; Zhang et al., 2020), and have also been noted in patients with autoimmune diseases (Takeuchi and Saito, 2017; Thewissen et al., 2007).

$\gamma \delta \mathrm{T}$ cells are a subset of unconventional non-MHC restricted innate-like T cells with cytotoxic effector functions and ability to regulate other immune cells (Lawand et al., 2017; Sabbaghi et al., 2020). Transcriptional analysis revealed expression of genes associated with cytotoxic effector functions in the $\gamma \delta$ T cells from COVID-19 patients, a feature that was not observed in $\gamma \delta \mathrm{T}$ cells from HCs or vaccinated individuals (Supplemental Fig. 5). Repertoire analysis of $\gamma \delta \mathrm{T}$ cells revealed oligoclonal expansion in majority of COVID-19 patients and a moderate dynamic response in vaccinated individuals (Figs. 4F,G; Supplemental Fig. 6C,D). Repertoire analysis also highlighted that the majority of larger $\gamma \delta$ T cell clones in COVID-19 patients are non- $\delta 2 \mathrm{~T}$ cells, and the same held true for vaccinated individuals (Fig. 4F and Supplemental Fig. 6D). In total, we observed expression of genes associated with cytotoxic effector functions among NK cells, CD4 T, CD8 T, and $\gamma \delta$ T cells in the setting of COVID-19, which likely contributes to both pathogen clearance and immune-mediated pathology associated with disease.

\section{Discussion}

In this study, we performed a granular, multimodal analysis of samples from COVID-19 patients and from healthy volunteers before and after receiving the SARS-CoV-2 BNT162b2 mRNA vaccine. While both infection and immunization elicited robust humoral responses, our analysis revealed dramatic differences in cell composition and transcriptional profiles of circulating immune cells in response to the two different immune challenges. 
Transcriptional analysis of pDCs and M1 macrophages revealed an upregulation of type I IFN production signature in cells from COVID-19 patients. Type I IFN mediates antiviral immunity, drives expression of a number of genes involved in viral clearance, and plays a critical role in the initiation of innate and adaptive immune responses during a viral infection (Wu and Metcalf, 2020). However, type I IFN signaling also promotes immunopathology through induction of aberrant inflammatory responses during acute viral infection (Major et al., 2020; Teijaro, 2016). Although the role of type I IFN signaling in COVID-19 remains to be fully elucidated, recent studies show that systemic production of type I IFN is negatively correlated with disease severity (Hadjadj et al., 2020; Liu et al., 2021), while excessive local production exacerbates lung tissue damage and correlates with increased morbidity and mortality (Broggi et al., 2020). Critically, induction of IFNs by viral infection can radically reshape antigen presentation, cellular trafficking, and terminal differentiation of lymphocytes (Gessani et al., 2014; Malmgaard, 2004). While SARS-CoV-2 infection provoked IFN response, we did not observe evidence of IFN induction by the BNT162b2 mRNA vaccine, suggesting that robust affinity maturation in response to viral antigens can occur in the absence of high levels of systemic IFN signaling.

Both SARS-CoV-2 infection and vaccination elicited SARS-CoV-2-specific antibody responses. While serum IgG levels remained high up to seven weeks after vaccination in all subjects, IgA levels declined. In addition to neutralizing pathogens at mucosal sites, IgA may be responsible for the majority of neutralization potential of serum in the immediate aftermath of SARS-CoV-2 infection (Sterlin et al., 2021). Prior studies have demonstrated that immunizations at mucosal sites elicit robust IgA responses locally, but fail to generate strong systemic IgA responses, while parenteral challenges induce stronger systemic response but sub-optimal protection at mucosal sites (Macpherson et al., 2008). One recent study suggests that neutralizing antibodies are rarely detected in nasal swabs from subjects who received the BNT162b2 SARS-CoV-2 mRNA vaccine (Planas et al., 2021), however, it remains to be determined whether the vaccine elicits protective mucosal immunity. Longitudinal assessment of mucosal and systemic humoral immune responses following immunization would provide valuable information regarding the nature and durability of protective humoral immunity induced by COVID-19 vaccines.

COVID-19 patients had a striking expansion of antibody-producing plasmablasts, with evidence of clonal cells in this cluster. Surprisingly, we did not detect appreciable expansion of plasmablasts in circulation of individuals immunized with SARS-CoV-2 BNT162b2 mRNA vaccine, despite a robust antibody response. This suggest that antibody-producing cells either migrate to their bone marrow niche at a time not captured by our weekly sampling, or stay resident in the tissues where they were generated. Further studies evaluating the presence of SARS-CoV-2-specific long-lived plasma cells in bone marrow following infection or immunization would shed light on the durability of protective immunity and aid in determining the optimal vaccine schedule and need for booster vaccines.

Recent studies have demonstrated that SARS-CoV-2 mRNA vaccines elicit potent antigenspecific GC responses (Lederer et al., 2020). We observed extensive accumulation of SHMs in memory B cells and plasma cells from COVID-19 patients, especially in B cells carrying BCR rearrangements that utilized $\mathrm{V}_{\mathrm{H}}$ elements previously implicated in anti-SARS-CoV-2 responses (Brouwer et al., 2020; Gaebler et al., 2021; Robbiani et al., 2020; Wang et al., 2021) (Fig. 3F). 
medRxiv preprint doi: https://doi.org/10.1101/2021.04.20.21255677; this version posted August 23, 2021. The copyright holder for this preprint (which was not certified by peer review) is the author/funder, who has granted medRxiv a license to display the preprint in perpetuity. All rights reserved. No reuse allowed without permission.

Consistent with the idea of long-lived plasma cell trafficking to the bone marrow, convalescent patients have a reduced presence of plasmablasts in circulation relative to acute illness, and the SHM footprint in the repertoire of the remaining cells was significantly diminished to what we observed at peak disease. Similarly, cTfh cells were also readily found among PBMCs from acute COVID-19 patients (Fig S4), suggestive of either an ongoing GC response or otherwise an inflammatory process that recruits these cells into circulation. We did not observe an increase in cTfh among individuals that received the mRNA vaccine, which may either reflect suboptimal time points for recovery of responding cTfh in immunized individuals, or that the systemic, and vastly more complicated, nature of infection generates more robust GC responses than the mRNA vaccine.

Sequelae of COVID-19 have included development of autoantibodies, but the reasons for this are not clear. In autoimmune diseases such as SLE, pathogenic autoantibodies were associated with strong IFN signatures. In parallel, we observed strong type I IFN signatures in plasmablasts during acute COVID-19. Strong antibody responses often correlate with more severe illness and antibody-dependent enhancement of pathology has been described in COVID-19 patients (Bastard et al., 2020; Cervia et al., 2021; Ehrenfeld et al., 2020; Gomes et al., 2021; Hansen et al., 2021; Zuniga et al., 2021). Augmented IFN signaling has also been implicated in production of pathogenic autoantibodies in systemic lupus erythematosus (SLE) (Akita et al., 2021; Rönnblom and Leonard, 2019). Additionally, a number of studies have highlighted the shared IFN-induced gene signature in lymphocytes from patients with autoimmune disease and in subjects following viral infections (Kyogoku et al., 2013; Rönnblom and Leonard, 2019). Our observation that B lymphocyte transcriptional programs in COVID-19 patients are dominated by dramatic upregulation of IFN-response genes may be important for understanding the immunopathology of COVID-19, as there is growing evidence that autoantibodies could be driving severe disease and long-term sequelae in some COVID-19 patients (Bastard et al., 2020; Ehrenfeld et al., 2020; Gomes et al., 2021; Zuniga et al., 2021). Conversely, IFN signaling could aid in the rapid production of antigen-specific antibodies by enhancing the overall magnitude of follicular B cell responses (Murira and Lamarre, 2016). Type I IFN has been shown to both enhance and impair specific antibody responses in viral infection (Daugan et al., 2016; Le Bon et al., 2001; Murira and Lamarre, 2016; Swanson et al., 2010). Interestingly, we observed that in COVID-19 patients, clonal responses were most evident among plasmablasts. On the other hand, clonal cells were found within memory and naïve B cell compartments at multiple time points in vaccinated individuals. It is possible that once analysis can be performed on patient samples stratified by disease severity and evaluated alongside a detailed time course following vaccination, we will be able to truly discern the impact of IFN on maturation of GC responses in the context of SARS-CoV-2 infection and vaccination.

In our study, plasmablasts in COVID-19 patients were characterized by a strong type I IFN gene expression signature relative to those in the periphery of healthy volunteers and vaccine recipients. While overzealous IFN response could favor extrafollicular plasma cell differentiation at the expense of affinity maturation of anti-viral responses (Braun et al., 2002; Soni et al., 2020), we observed accumulation of SHMs in the repertoire of plasmablasts and memory cells from COVID-19 patients, as well as vaccinated individuals. While an earlier study of postmortem thoracic lymph nodes from patients with severe COVID-19 described found muted 
medRxiv preprint doi: https://doi.org/10.1101/2021.04.20.21255677; this version posted August 23, 2021. The copyright holder for this preprint (which was not certified by peer review) is the author/funder, who has granted medRxiv a license to display the preprint in perpetuity.

All rights reserved. No reuse allowed without permission.

GC response (Kaneko et al., 2020), our observation of SHMs in plasmablasts may be reflective of the fact that we are studying patients with less severe disease.

Recent studies emphasize generation of antigen-specific $\mathrm{T}$ cells in protective immunity against SARS-CoV-2 infection and it is becoming increasingly clear that successful vaccines need to engage the cellular adaptive immune response (Jeyanathan et al., 2020; Oja et al., 2020; Sauer and Harris, 2020). Indeed, humoral immune responses may be less effective against new SARSCoV-2 variants (Hu et al., 2021; Planas et al., 2021). Conversely, SARS-CoV-2-specific CD8 T cell responses, which target a broad range of epitopes, remain largely intact against new variants presently in circulation (Redd et al., 2021). Our analysis revealed that both SARS-CoV-2 infection and, to a lesser degree, vaccination elicit clonal CD8 effector T cell responses. We also observed a strong clonal response in CD8/CD26 $\mathrm{T}_{\mathrm{EM}}$ cells in all volunteers following immunization - a feature of adaptive response that was notably absent in COVID-19 patients. Robust SARS-CoV-2-specific T cell immunity is maintained for up to eight months after infection, but as yet it is not clear how durable $\mathrm{T}$ cell responses are following vaccination (Dan et al., 2021). However, the clonal expansion of CD8 $\mathrm{T}_{\mathrm{EM}}$ cells we observed in vaccinated volunteers suggests that vaccination elicits memory $\mathrm{T}$ cell responses, which are likely to be longlived.

Peripheral immune cells of COVID-19 patients were enriched in T cells, NK cells, and $\gamma \delta$ T cells with a highly activated phenotype and elevated expression of genes associated with cytotoxic effector functions ( $G Z M A, G Z M B, G Z M H, P R F 1, G N L Y, N K G 7$, and $I L-32$ ). We observed the presence of cytotoxic CD4 T cells in COVID-19 patients that were largely absent in healthy volunteers following immunization. While hyperactivation of inflammatory responses and cytotoxic cells may contribute to immunopathology in severe illness, in mild and moderate disease, these features are indicative of protective immune responses and resolution of infection (Chen and John Wherry, 2020; Gustine and Jones, 2021).

Our study, together with others, underscores the fine balance between antiviral immune responses that achieve clearance of the infection and durable protective immunity, and those that lead to inflammation and immunopathology. Better understanding of the immunological features associated with protective immunity, immunopathology, and durability of protective immunological memory will aid not only in better treatments for viral diseases, but also facilitate the rapid development of effective vaccines for new and re-emerging viral diseases that threaten public health. 
medRxiv preprint doi: https://doi.org/10.1101/2021.04.20.21255677; this version posted August 23, 2021. The copyright holder for this preprint (which was not certified by peer review) is the author/funder, who has granted medRxiv a license to display the preprint in perpetuity.

\section{Materials and methods}

\section{Patients and sample collection}

Peripheral blood samples were drawn from both outpatients and hospitalized patients with confirmed COVID-19 at NYU Langone Health. SARS-CoV-2 was detected in patients' nasopharyngeal swab using the Cobras SARS-CoV-2 real time PCR under EUA. Peripheral blood was collected in accordance with a NYU Institutional Review Board protocols (IRB 1802035, 18-02037 and 20-00463). Samples were de-identified and assigned coded identification numbers prior to analysis.

Whole blood was collected in commercially-available heparin-coated tubes (BD). Plasma was collected from whole blood by centrifugation at $2000 \mathrm{x} g$ at $4^{\circ} \mathrm{C}$, aliquoted, and stored at $-20^{\circ} \mathrm{C}$. For serum collection, whole blood was collected in a serum separator tube (SST) tubes (BD). The blood was allowed to clot undisturbed at room temperature for 30-45 minutes and the clot was removed by centrifugation at $2000 \times \mathrm{g}$ at $4^{\circ} \mathrm{C}$, the serum aliquoted and stored at $-20^{\circ} \mathrm{C}$.

\section{$\underline{\text { PBMC isolation }}$}

PBMCs were isolated from peripheral blood by diluting whole blood in gradient centrifugation using Ficoll-Paque PLUS (GE Healthcare) and SepMate ${ }^{\mathrm{TM}}$ PBMC Isolation Tubes (Stemcell) according to the manufacturer's instructions. Buffy coat PBMCs were cryopreserved in FBS supplemented with 10\% DMSO and stored in liquid nitrogen.

\section{Single-cell RNA-seq}

Sample processing of COVID-19 patient samples for scRNA-seq was performed in the ABSL3 facility of NYU Grossman School of Medicine (New York, NY), in accordance with its Biosafety Manual and Standard Operating Procedures. Single cell transcriptome profiling of PBMCs was carried out using the Chromium Next GEM Single Cell 5' Library \& Gel Bead Kit (v1.1) and Chromium controller (10X Genomics). PBMCs were thawed and live cells were enriched using Miltenyi Live Enrichment Kit to ensure viability of all samples is over 95\% prior to staining. To enable multiplexing and doublet detection, cells were stained with barcoded antibodies for CITE-seq and cell hashing described previously (Buus et al., 2020; Mimitou et al., 2019; Stoeckius et al., 2017; Stoeckius et al., 2018). Expression of selected surface protein markers (previously titrated antibody panel in supplemental materials) (Buus et al., 2020) was achieved by staining with barcoded antibodies as described (Stoeckius et al., 2017). Briefly, approximately 200,000 cells per sample were resuspended in staining buffer (PBS, 2\% BSA, $0.01 \%$ Tween) and incubated for 10 minutes with Fc block (TruStain FcX, Biolegend; FcR blocking reagent, Miltenyi). Cells were then incubated with barcoded antibodies for $30 \mathrm{~min}$ at $4{ }^{\circ} \mathrm{C}$. After staining, cells were washed 3 times in staining buffer. After the final wash, cells were resuspended in PBS $+0.04 \%$ BSA, filtered, and counted. Cells were pooled and loaded onto the Chromium chips ( 5 samples per lane, targeting 5,000 cells per sample). The single-cell capturing, barcoding, and cDNA library preparation were performed using the Chromium Next GEM Single Cell 5' Library \& Gel Bead Kit following the protocols recommended by the manufacturer. HTO and ADT additive oligonucleotides were spiked into the cDNA amplification 
medRxiv preprint doi: https://doi.org/10.1101/2021.04.20.21255677; this version posted August 23, 2021. The copyright holder for this preprint (which was not certified by peer review) is the author/funder, who has granted medRxiv a license to display the preprint in perpetuity. All rights reserved. No reuse allowed without permission.

PCR and the ADT and HTO libraries were prepared as described previously (Stoeckius et al., 2017; Stoeckius et al., 2018). The cDNA fraction was processed according to the 10x Genomics Single Cell V(D)J protocol to generate the transcriptome library and the TCR $\alpha / \beta$ and BCR libraries. To amplify TCR $\gamma / \delta$ transcripts, we utilized a two-step PCR similar to TCR $\alpha / \beta$ approach described previously (Mimitou et al., 2019). Libraries were pooled to desired quantities and sequenced on a NovaSeq 6000 (S2 flowcell: recipe 26 cycles read 1, 8 cycles index, 91 cycles read 2). Reads were trimmed as required for downstream processing.

\section{$\underline{\text { Single cell RNA-seq data processing }}$}

The Cellranger software suite (https://support.10xgenomics.com/single-cell-geneexpression/software/pipelines/latest/what-is-cell-ranger) from $10 \mathrm{X}$ was used to demultiplex cellular barcodes, align reads to the human genome (GRCh38 ensemble, http://useast.ensembl.org/Homo_sapiens/Info/Index) and perform UMI counting. ADT and HTO count matrices were generated by kallisto kb-count v0.24.1 (Bray et al., 2016; Melsted et al., 2021) and HTOs demultiplexed by HTODemux from Seurat v4.0.0 (Stuart et al., 2019). Following cellranger all other processing was performed in R v4.0.3 (R Core Team, 2018). From filtered counts Seurat was used to process the single cell data, generate UMAP representation based on totalVI (Gayoso et al., 2021) dimension reduction of RNA and ADT modalities. RNA was normalized and batch-corrected by totalVI, while ADT values were corrected by the built-in integration function FindIntegrationAnchors in Seurat. Clustering was performed by the Louvain algorithm (Blondel et al., 2008) and cell type identification was determined by clustering, SingleR annotations, corrected ADT levels and canonical markers for various immune cell subsets. Further sub-clustering was performed on Myeloid, B, conventional T and innate-like T and NK cells to identify 32 individual populations. BCR/TCR sequences were processed by cellranger VDJ and added to the metadata of the combined Seurat object for each sample. Statistical differences in the percentages of cell type clusters were assessed by linear mixed models with disease and time point as fixed effects and subject as a random effect. Significance was determined by an ANOVA of each linear mixed model and post-hoc pairwise comparison of estimated marginal means. GSVA of select immune cell subsets were performed in $\mathrm{R}$ with the GSVA package v1.38 (Hänzelmann et al., 2013) with various named gene sets from MSigDB (http://www.gsea-msigdb.org/gsea/index.jsp). Differential expression between cell types and between cells from HC, immunized individuals and COVID-19 samples were also assessed by Wilcox test with Benjamin-Hochberg p-value adjustment.

\section{Multiplex bead-binding assay for antibody profiling}

Multiplex bead-binding assay was carried out as described (Hattori et al., 2021), with the following modifications. Briefly, we produced the spike and RBD proteins as described (Hattori et al., 2021) and purchased biotinylated nucleocapsid protein (Sino Biological, catalog number 40588-V27B-B). We used MultiCyt ${ }^{\circledR}$ QBeads ${ }^{\circledR}$ Streptavidin Coated panel QSAv1,2,3 and 5 (Sartorius catalog number 90792) to immobilize SARS-CoV-2 antigens; Spike to QSAv1, Nucleocapsid to QSAv2, the receptor-binding-domain of Spike (RBD) to QSAv3, and biotin only to QSAv5. The antigens were diluted to $25 \mathrm{nM}$ in PBS with $0.5 \%$ BSA and mixed with the same volume of the twice-washed QBeads. We detected antigen-specific antibodies in heatinactivated serum or plasma using anti-human IgG-Alexa 488 (Jackson Immunoresearch; catalog 
medRxiv preprint doi: https://doi.org/10.1101/2021.04.20.21255677; this version posted August 23, 2021. The copyright holder for this preprint (which was not certified by peer review) is the author/funder, who has granted medRxiv a license to display the preprint in perpetuity.

All rights reserved. No reuse allowed without permission.

number 109-545-098, 1:800 in PBS 0.1\% Tween 20 and with $1 \%$ BSA), anti-human IgA-PE (Jackson Immunoresearch; catalog number 109-115-011, 1:100) and anti-human IgMDyLight405 (Jackson Immunoresearch; catalog number 709-475-073, 1:200). We measured the samples on a Yeti ZE5 Cell Analyzer (Bio-Rad) and analyzed the data using FlowJo (BD, version 10.7.1). 
medRxiv preprint doi: https://doi.org/10.1101/2021.04.20.21255677; this version posted August 23, 2021. The copyright holder for this preprint (which was not certified by peer review) is the author/funder, who has granted medRxiv a license to display the preprint in perpetuity.

\section{Acknowledgements}

We are grateful for support of this work from NYU Grossman School of Medicine. Work in Dr. Koralov's laboratory was further supported by the NIH R01 grant (HL-125816), LEO Foundation Grant (LF-OC-20-000351), NYU Cancer Center Pilot Grant (P30CA016087), the Judith and Stewart Colton Center for Autoimmunity Pilot grant. Presented work was also supported by NIH grant R21 AI158997, R01 CA194864 and R01 CA212608 to S.K.; NIH grants AI1 14852 and AI082630 to R.S.H.; and AI148574 to M.J.M. TBB and NØ are supported by the Danish Cancer Society (Kræftens Bekæmpelse), the Danish Council for Independent Research (Danmarks Frie Forskningsfond) and the LEO Foundation. We thank the NYU Vaccine Center team, everyone at NYU Genome Technology Center, and Dr. Heguy in particular, for technical assistance and support.

\section{Disclosures}

MJM reported potential competing interests: laboratory research and clinical trials contracts with Lilly, Pfizer (exclusive of the current work), and Sanofi for vaccines or MAB vs SARS-CoV-2; contract funding from USG/HHS/BARDA for research specimen characterization and repository; research grant funding from USG/HHS/NIH for SARS-CoV-2 vaccine and MAB clinical trials; personal fees from Meissa Vaccines, Inc. and Pfizer for Scientific Advisory Board service.

PS is listed as a co-inventor on a patent application related to CITE-seq technology used (US provisional patent application 62/515-180).

The authors have no additional financial interests. 
medRxiv preprint doi: https://doi.org/10.1101/2021.04.20.21255677; this version posted August 23, 2021. The copyright holder for this preprint (which was not certified by peer review) is the author/funder, who has granted medRxiv a license to display the preprint in perpetuity. All rights reserved. No reuse allowed without permission.

\section{Figure Legends}

\section{Figure 1. Single-cell landscape of immunological responses to COVID-19 and SARS-CoV-2 BNT162b2 mRNA vaccine}

a. UMAP representation of over 123,000 PBMCs by scRNA-seq, clustered and colored by indicated cell type. Clusters identified based on gene expression and surface epitopes.

b. UMAP visualization of PBMCs from and COVID-19-naïve healthy donors (blue), healthy volunteers before receiving the BNT162b2 mRNA vaccine (blue), healthy volunteers after receiving the BNT162b2 mRNA vaccine (orange), and COVID-19 patients (red).

c-f. UMAP representation of subclustered myeloid (c), B cell (d), T cell (e), and innate and unconventional T cell (f) populations colored and labeled by cell type. (g,h) Graphs highlight specific populations that exhibited significant differences between healthy volunteers and COVID-19 patients. Vaccine samples are shown as weeks after first vaccine dose. COVID-19 patient samples were split by days post-onset (DPO) of symptoms into early/acute ( $<8 \mathrm{DPO})$, late (8-13 DPO), and convalescent ( $>13 \mathrm{DPO})$. Connected lines indicate repeated measurements for the same subjects. P-values are reported in Supplementary Figure 1B.

\section{Figure 2. Myeloid cell expression of type I interferon pathway.}

a. Scaled normalized expression of IRF7, IRF8, and LILRA4 in 8 identified myeloid populations (left) and plotted for specific expression in pDCs from HC, Vaccine samples and COVID-19 patients (right).

b. Scaled and normalized expression of IFN production-associated genes in pDCs based on gene ontology (GO) gene set for type I IFN production (GO:0032606).

\section{Figure 3. Maturation of $B$ cell responses}

a. SARS-CoV-2-specific antibody titers were assessed for COVID-19 patients and healthy volunteers using a Multiplex Bead Binding Assay (MBBA). We assayed IgG, IgA, and IgM antibody titers specific for SARS-CoV-2 Spike, RBD, and NC. Anti-RBD IgG (top) and IgA (bottom) are shown for COVID-19 patients and healthy donors (left), and for healthy volunteers who received the SARS-CoV-2 BNT162b2 mRNA vaccine (right), colored by subject. COVID19 patient samples were split into early/acute ( $<8 \mathrm{DPO})$, late (8-13 DPO), and convalescent $(>13 \mathrm{DPO})$. Connected lines indicate repeated measurements for the same subjects.

b. GSVA analysis of plasmablasts in cells from HC, Vaccine and COVID-19 (bottom color bar) patients from the Hallmark gene set (Liberzon et al., 2015) and colored by oxygen requirement (top color bar) which is a clinical parameter defined as the fraction of inspired oxygen, where $21 \%$ represents oxygen content of room air without supplementation. Vaccine and $\mathrm{HC}$ cells are 
medRxiv preprint doi: https://doi.org/10.1101/2021.04.20.21255677; this version posted August 23, 2021. The copyright holder for this preprint (which was not certified by peer review) is the author/funder, who has granted medRxiv a license to display the preprint in perpetuity. All rights reserved. No reuse allowed without permission.

colored at 21\%. COVID-19 patient samples were split into early/acute ( $<8 \mathrm{DPO})$, late $(8-13$ DPO), and convalescent (>13DPO).

c. Oxygen requirement against GSVA enrichment score for interferon alpha response gene set as shown in b. $\mathrm{p}$ and tau values are determined by a Kendall rank correlation test.

d. Clonal populations based on individual B cell IGH chain CDR3 sequence. CDR3 sequences occurring in at least 2 cells are colored blue, while any CDR3 sequences in at least 3 cells are colored uniquely in cells from Vaccinated (top) and COVID-19 patient samples (bottom)

e. Number of mismatched bases according to IgBlast results of recovered $\mathrm{V}_{\mathrm{H}}$ gene sequences in plasmablasts (top) memory (middle) and naïve (bottom) B cell subsets in cells from HC, Vaccinated and COVID-19 patient samples. P-value were determined by Wilcox test.

f. Frequency of highly mutated $\mathrm{V}_{\mathrm{H}}$ gene sequences in experienced memory and plasmablasts. Frequency is normalized by the total number of memory and plasmablasts in each patient group. Asterisks indicate $\mathrm{V}_{\mathrm{H}}$ gene sequences previously implicated in SARS-CoV-2 infection and vaccination (Brouwer et al., 2020; Gaebler et al., 2021; Robbiani et al., 2020; Wang et al., 2021).

Figure 4. Cytotoxic responses and clonality of conventional and innate-like $T$ cells in COVID-19 and SARS-CoV-2 vaccine recipients

a,b. Graphs of cell percentages of select cytotoxic cell populations that exhibited significant differences between COVID-19-naïve donors and healthy volunteers before receiving the BNT162b2 mRNA vaccine (blue), healthy volunteers after receiving the BNT162b2 mRNA vaccine (orange), and COVID-19 patients (red). P-values are determined by an ANOVA of linear mixed models and post-hoc pairwise comparison of estimated marginal means.

c. Average per-sample scaled expression of genes associated with cytotoxic effector function from the gene set $\mathrm{T}$ cell mediated cytotoxicity (GO:0001913) in proliferating NK and conventional $\mathrm{T}$ cells.

d. UMAP visualization of clonal CD8 T cells from COVID-19 patients (left) and healthy volunteers after receiving the BNT162b2 mRNA vaccine (right). Clonality is determined by the CDR3 sequence in TCR $\beta$ chain. Identical CDR3 sequences in at least 3 cells are colored uniquely.

e. UMAP visualization of clonal $\gamma \delta$ T cells from COVID-19 patients (left) and healthy volunteers after receiving the BNT162b2 mRNA vaccine (right). Clonality is determined by the CDR3 sequence in TCR $\delta$ chain. Identical CDR3 sequences in at least 3 cells are colored uniquely.

f. Bar graphs showing clonal repertoire distribution among CD8 $\mathrm{T}_{\mathrm{EM}}$ and $\mathrm{T}_{\text {eff }}$ cells based on TCR $\beta$ CDR3 sequence in one representative sample set from acute COVID-19 patient and from time course of a vaccinated individual. Polyclonal cells in grey. Circos plots of frequencies of V $\beta$ and $\mathrm{J} \beta$ usage are shown and colored uniquely by CDR3 sequences as in $\mathrm{c}$. 
medRxiv preprint doi: https://doi.org/10.1101/2021.04.20.21255677; this version posted August 23, 2021. The copyright holder for this preprint (which was not certified by peer review) is the author/funder, who has granted medRxiv a license to display the preprint in perpetuity.

All rights reserved. No reuse allowed without permission.

g. Bar graphs showing clonal repertoire distribution among $\gamma \delta \mathrm{T}$ cells based on TCR $\delta$ CDR3 sequence in one representative sample set from acute COVID-19 patient and from time course of a vaccinated individual. Polyclonal cells in grey. Circos plots of frequencies of V $\delta$ and $\mathrm{J} \delta$ usage is shown and colored uniquely by CDR3 sequences as in $\mathrm{d}$. 


\section{References:}

Akita, K., K. Yasaka, T. Shirai, T. Ishii, H. Harigae, and H. Fujii. 2021. Interferon $\alpha$ Enhances B Cell Activation Associated With FOXM1 Induction: Potential Novel Therapeutic Strategy for Targeting the Plasmablasts of Systemic Lupus Erythematosus. Frontiers in Immunology 11:

Aran, D., A.P. Looney, L. Liu, E. Wu, V. Fong, A. Hsu, S. Chak, R.P. Naikawadi, P.J. Wolters, A.R. Abate, A.J. Butte, and M. Bhattacharya. 2019. Reference-based analysis of lung single-cell sequencing reveals a transitional profibrotic macrophage. Nature Immunology 20:163-172.

Bastard, P., L.B. Rosen, Q. Zhang, E. Michailidis, H.-H. Hoffmann, Y. Zhang, K. Dorgham, Q. Philippot, J. Rosain, V. Béziat, J. Manry, E. Shaw, L. Haljasmägi, P. Peterson, L. Lorenzo, L. Bizien, S. Trouillet-Assant, K. Dobbs, A.A. de Jesus, A. Belot, A. Kallaste, E. Catherinot, Y. Tandjaoui-Lambiotte, J. Le Pen, G. Kerner, B. Bigio, Y. Seeleuthner, R. Yang, A. Bolze, A.N. Spaan, O.M. Delmonte, M.S. Abers, A. Aiuti, G. Casari, V. Lampasona, L. Piemonti, F. Ciceri, K. Bilguvar, R.P. Lifton, M. Vasse, D.M. Smadja, M. Migaud, J. Hadjadj, B. Terrier, D. Duffy, L. Quintana-Murci, D. van de Beek, L. Roussel, D.C. Vinh, S.G. Tangye, F. Haerynck, D. Dalmau, J. Martinez-Picado, P. Brodin, M.C. Nussenzweig, S. Boisson-Dupuis, C. Rodríguez-Gallego, G. Vogt, T.H. Mogensen, A.J. Oler, J. Gu, P.D. Burbelo, J.I. Cohen, A. Biondi, L.R. Bettini, M. Angio, P. Bonfanti, P. Rossignol, J. Mayaux, F. Rieux-Laucat, E.S. Husebye, F. Fusco, M.V. Ursini, L. Imberti, A. Sottini, S. Paghera, E. Quiros-Roldan, C. Rossi, R. Castagnoli, D. Montagna, A. Licari, G.L. Marseglia, X. Duval, J. Ghosn, J.S. Tsang, R. Goldbach-Mansky, K. Kisand, M.S. Lionakis, A. Puel, S.-Y. Zhang, S.M. Holland, G. Gorochov, E. Jouanguy, C.M. Rice, A. Cobat, L.D. Notarangelo, L. Abel, H.C. Su, and J.-L. Casanova. 2020. Autoantibodies against type I IFNs in patients with life-threatening COVID-19. Science 370:eabd4585.

Bentebibel, S.E., S. Lopez, G. Obermoser, N. Schmitt, C. Mueller, C. Harrod, E. Flano, A. Mejias, R.A. Albrecht, D. Blankenship, H. Xu, V. Pascual, J. Banchereau, A. GarciaSastre, A.K. Palucka, O. Ramilo, and H. Ueno. 2013. Induction of ICOS+CXCR3+CXCR5+ TH cells correlates with antibody responses to influenza vaccination. Sci Transl Med 5:176ra132.

Blondel, V.D., J.-L. Guillaume, R. Lambiotte, and E. Lefebvre. 2008. Fast unfolding of communities in large networks. Journal of Statistical Mechanics: Theory and Experiment 2008:P10008.

Bos, R., L. Rutten, J.E.M. van der Lubbe, M.J.G. Bakkers, G. Hardenberg, F. Wegmann, D. Zuijdgeest, A.H. de Wilde, A. Koornneef, A. Verwilligen, D. van Manen, T. Kwaks, R. Vogels, T.J. Dalebout, S.K. Myeni, M. Kikkert, E.J. Snijder, Z. Li, D.H. Barouch, J. Vellinga, J.P.M. Langedijk, R.C. Zahn, J. Custers, and H. Schuitemaker. 2020. Ad26 vector-based COVID-19 vaccine encoding a prefusion-stabilized SARS-CoV-2 Spike immunogen induces potent humoral and cellular immune responses. NPJ Vaccines 5:91.

Braun, D., I. Caramalho, and J. Demengeot. 2002. IFN- $\alpha / \beta$ enhances BCR-dependent B cell responses. International Immunology 14:411-419.

Bray, N.L., H. Pimentel, P. Melsted, and L. Pachter. 2016. Near-optimal probabilistic RNA-seq quantification. Nature Biotechnology 34:525-527. 
Broggi, A., S. Ghosh, B. Sposito, R. Spreafico, F. Balzarini, A. Lo Cascio, N. Clementi, M. De Santis, N. Mancini, F. Granucci, and I. Zanoni. 2020. Type III interferons disrupt the lung epithelial barrier upon viral recognition. Science 369:706.

Brouwer, P.J.M., T.G. Caniels, K. van der Straten, J.L. Snitselaar, Y. Aldon, S. Bangaru, J.L. Torres, N.M.A. Okba, M. Claireaux, G. Kerster, A.E.H. Bentlage, M.M. van Haaren, D. Guerra, J.A. Burger, E.E. Schermer, K.D. Verheul, N. van der Velde, A. van der Kooi, J. van Schooten, M.J. van Breemen, T.P.L. Bijl, K. Sliepen, A. Aartse, R. Derking, I. Bontjer, N.A. Kootstra, W.J. Wiersinga, G. Vidarsson, B.L. Haagmans, A.B. Ward, G.J. de Bree, R.W. Sanders, and M.J. van Gils. 2020. Potent neutralizing antibodies from COVID-19 patients define multiple targets of vulnerability. Science 369:643-650.

Buus, T.B., A. Herrera, E. Ivanova, E. Mimitou, A. Cheng, T. Papagiannakopoulos, P. Smibert, N. Ødum, and S.B. Koralov. 2020. Improving oligo-conjugated antibody signal in multimodal single-cell analysis. bioRxiv 2020.2006.2015.153080.

Cervia, C., J. Nilsson, Y. Zurbuchen, A. Valaperti, J. Schreiner, A. Wolfensberger, M.E. Raeber, S. Adamo, S. Weigang, M. Emmenegger, S. Hasler, P.P. Bosshard, E. De Cecco, E. Bächli, A. Rudiger, M. Stüssi-Helbling, L.C. Huber, A.S. Zinkernagel, D.J. Schaer, A. Aguzzi, G. Kochs, U. Held, E. Probst-Müller, S.K. Rampini, and O. Boyman. 2021. Systemic and mucosal antibody responses specific to SARS-CoV-2 during mild versus severe COVID-19. J Allergy Clin Immunol 147:545-557.e549.

Chen, Z., and E. John Wherry. 2020. T cell responses in patients with COVID-19. Nature Reviews Immunology 20:529-536.

Cheng, Y., H. Zhao, P. Song, Z. Zhang, J. Chen, and Y.-H. Zhou. 2019. Dynamic changes of lymphocyte counts in adult patients with severe pandemic H1N1 influenza A. Journal of Infection and Public Health 12:878-883.

Chodick, G., L. Tene, T. Patalon, S. Gazit, A.B. Tov, D. Cohen, and K. Muhsen. 2021. The effectiveness of the first dose of BNT162b2 vaccine in reducing SARS-CoV-2 infection 13-24 days after immunization: real-world evidence. medRxiv 2021.2001.2027.21250612.

Crotty, S. 2019. T Follicular Helper Cell Biology: A Decade of Discovery and Diseases. Immunity 50:1132-1148.

Dan, J.M., J. Mateus, Y. Kato, K.M. Hastie, E.D. Yu, C.E. Faliti, A. Grifoni, S.I. Ramirez, S. Haupt, A. Frazier, C. Nakao, V. Rayaprolu, S.A. Rawlings, B. Peters, F. Krammer, V. Simon, E.O. Saphire, D.M. Smith, D. Weiskopf, A. Sette, and S. Crotty. 2021. Immunological memory to SARS-CoV-2 assessed for up to 8 months after infection. Science 371:eabf4063.

Daugan, M., A. Murira, B.C. Mindt, A. Germain, E. Tarrab, P. Lapierre, J.H. Fritz, and A. Lamarre. 2016. Type I Interferon Impairs Specific Antibody Responses Early during Establishment of LCMV Infection. Frontiers in Immunology 7:

Desai, N., A. Neyaz, A. Szabolcs, A.R. Shih, J.H. Chen, V. Thapar, L.T. Nieman, A. Solovyov, A. Mehta, D.J. Lieb, A.S. Kulkarni, C. Jaicks, K.H. Xu, M.J. Raabe, C.J. Pinto, D. Juric, I. Chebib, R.B. Colvin, A.Y. Kim, R. Monroe, S.E. Warren, P. Danaher, J.W. Reeves, J. Gong, E.H. Rueckert, B.D. Greenbaum, N. Hacohen, S.M. Lagana, M.N. Rivera, L.M. Sholl, J.R. Stone, D.T. Ting, and V. Deshpande. 2020. Temporal and spatial heterogeneity of host response to SARS-CoV-2 pulmonary infection. Nature Communications 11:6319.

Ebinger, J.E., J. Fert-Bober, I. Printsev, M. Wu, N. Sun, J.C. Prostko, E.C. Frias, J.L. Stewart, J.E. Van Eyk, J.G. Braun, S. Cheng, and K. Sobhani. 2021. Antibody responses to the 
medRxiv preprint doi: https://doi.org/10.1101/2021.04.20.21255677; this version posted August 23, 2021. The copyright holder for this preprint

(which was not certified by peer review) is the author/funder, who has granted medRxiv a license to display the preprint in perpetuity.

All rights reserved. No reuse allowed without permission.

BNT162b2 mRNA vaccine in individuals previously infected with SARS-CoV-2. Nature Medicine

Ehrenfeld, M., A. Tincani, L. Andreoli, M. Cattalini, A. Greenbaum, D. Kanduc, J. AlijotasReig, V. Zinserling, N. Semenova, H. Amital, and Y. Shoenfeld. 2020. Covid-19 and autoimmunity. Autoimmun Rev 19:102597.

Gaebler, C., Z. Wang, J.C.C. Lorenzi, F. Muecksch, S. Finkin, M. Tokuyama, A. Cho, M. Jankovic, D. Schaefer-Babajew, T.Y. Oliveira, M. Cipolla, C. Viant, C.O. Barnes, Y. Bram, G. Breton, T. Hägglöf, P. Mendoza, A. Hurley, M. Turroja, K. Gordon, K.G. Millard, V. Ramos, F. Schmidt, Y. Weisblum, D. Jha, M. Tankelevich, G. MartinezDelgado, J. Yee, R. Patel, J. Dizon, C. Unson-O’Brien, I. Shimeliovich, D.F. Robbiani, Z. Zhao, A. Gazumyan, R.E. Schwartz, T. Hatziioannou, P.J. Bjorkman, S. Mehandru, P.D. Bieniasz, M. Caskey, and M.C. Nussenzweig. 2021. Evolution of antibody immunity to SARS-CoV-2. Nature 591:639-644.

Gayoso, A., Z. Steier, R. Lopez, J. Regier, K.L. Nazor, A. Streets, and N. Yosef. 2021. Joint probabilistic modeling of single-cell multi-omic data with totalVI. Nature Methods 18:272-282.

Gessani, S., L. Conti, M. Del Cornò, and F. Belardelli. 2014. Type I interferons as regulators of human antigen presenting cell functions. Toxins (Basel) 6:1696-1723.

Gomes, C., M. Zuniga, K.A. Crotty, K. Qian, L.H. Lin, K.V. Argyropoulos, H. Li, P. Cotzia, and A. Rodriguez. 2021. Autoimmune anti-DNA antibodies predict disease severity in COVID-19 patients. medRxiv 2021.2001.2004.20249054.

Gustine, J.N., and D. Jones. 2021. Immunopathology of Hyperinflammation in COVID-19. Am J Pathol 191:4-17.

Hadjadj, J., N. Yatim, L. Barnabei, A. Corneau, J. Boussier, N. Smith, H. Péré, B. Charbit, V. Bondet, C. Chenevier-Gobeaux, P. Breillat, N. Carlier, R. Gauzit, C. Morbieu, F. Pène, N. Marin, N. Roche, T.-A. Szwebel, S.H. Merkling, J.-M. Treluyer, D. Veyer, L.

Mouthon, C. Blanc, P.-L. Tharaux, F. Rozenberg, A. Fischer, D. Duffy, F. Rieux-Laucat, S. Kernéis, and B. Terrier. 2020. Impaired type I interferon activity and inflammatory responses in severe COVID-19 patients. Science 369:718.

Hansen, C.B., I. Jarlhelt, L. Pérez-Alós, L. Hummelshøj Landsy, M. Loftager, A. Rosbjerg, C. Helgstrand, J.R. Bjelke, T. Egebjerg, J.G. Jardine, C. Sværke Jørgensen, K. Iversen, R. Bayarri-Olmos, P. Garred, and M.O. Skjoedt. 2021. SARS-CoV-2 Antibody Responses Are Correlated to Disease Severity in COVID-19 Convalescent Individuals. J Immunol 206:109-117.

Hänzelmann, S., R. Castelo, and J. Guinney. 2013. GSVA: gene set variation analysis for microarray and RNA-Seq data. BMC Bioinformatics 14:7.

Hattori, T., A. Koide, T. Panchenko, L.A. Romero, K.W. Teng, A.D. Corrado, and S. Koide. 2021. Multiplex bead binding assays using off-the-shelf components and common flow cytometers. Journal of Immunological Methods 490:112952.

Herati, R.S., A. Muselman, L. Vella, B. Bengsch, K. Parkhouse, D. Del Alcazar, J. Kotzin, S.A. Doyle, P. Tebas, S.E. Hensley, L.F. Su, K.E. Schmader, and E.J. Wherry. 2017. Successive annual influenza vaccination induces a recurrent oligoclonotypic memory response in circulating T follicular helper cells. Science Immunology 2:eaag2152.

Herati, R.S., L.V. Silva, L.A. Vella, A. Muselman, C. Alanio, B. Bengsch, R.K. Kurupati, S. Kannan, S. Manne, A.V. Kossenkov, D.H. Canaday, S.A. Doyle, H.C.J. Ertl, K.E. 
Schmader, and E.J. Wherry. 2019. Vaccine-induced ICOS+CD38+ cTfh are sensitive biosensors of age-related changes in inflammatory pathways. bioRxiv 711911.

Hirano, T., K. Ishihara, and M. Hibi. 2000. Roles of STAT3 in mediating the cell growth, differentiation and survival signals relayed through the IL-6 family of cytokine receptors. Oncogene 19:2548-2556.

Hsieh, C.L., J.A. Goldsmith, J.M. Schaub, A.M. DiVenere, H.C. Kuo, K. Javanmardi, K.C. Le, D. Wrapp, A.G. Lee, Y. Liu, C.W. Chou, P.O. Byrne, C.K. Hjorth, N.V. Johnson, J. Ludes-Meyers, A.W. Nguyen, J. Park, N. Wang, D. Amengor, J.J. Lavinder, G.C. Ippolito, J.A. Maynard, I.J. Finkelstein, and J.S. McLellan. 2020. Structure-based design of prefusion-stabilized SARS-CoV-2 spikes. Science 369:1501-1505.

Hu, J., P. Peng, K. Wang, L. Fang, F.-y. Luo, A.-s. Jin, B.-z. Liu, N. Tang, and A.-1. Huang. 2021. Emerging SARS-CoV-2 variants reduce neutralization sensitivity to convalescent sera and monoclonal antibodies. Cellular \& Molecular Immunology 18:1061-1063.

Jackson, K.J., Y. Liu, K.M. Roskin, J. Glanville, R.A. Hoh, K. Seo, E.L. Marshall, T.C. Gurley, M.A. Moody, B.F. Haynes, E.B. Walter, H.X. Liao, R.A. Albrecht, A. García-Sastre, J. Chaparro-Riggers, A. Rajpal, J. Pons, B.B. Simen, B. Hanczaruk, C.L. Dekker, J. Laserson, D. Koller, M.M. Davis, A.Z. Fire, and S.D. Boyd. 2014. Human responses to influenza vaccination show seroconversion signatures and convergent antibody rearrangements. Cell Host Microbe 16:105-114.

Jeewandara, C., D. Jayathilaka, L. Gomes, A. Wijewickrama, E. Narangoda, D. Idampitiya, D. Guruge, R. Wijayamuni, S. Manilgama, G.S. Ogg, C.W. Tan, L.-F. Wang, and G.N. Malavige. 2021. SARS-CoV-2 neutralizing antibodies in patients with varying severity of acute COVID-19 illness. Scientific Reports 11:2062.

Jeyanathan, M., S. Afkhami, F. Smaill, M.S. Miller, B.D. Lichty, and Z. Xing. 2020. Immunological considerations for COVID-19 vaccine strategies. Nature Reviews Immunology 20:615-632.

Juno, J.A., D. van Bockel, S.J. Kent, A.D. Kelleher, J.J. Zaunders, and C.M. Munier. 2017. Cytotoxic CD4 T Cells-Friend or Foe during Viral Infection? Front Immunol 8:19.

Kane, M., T.M. Zang, S.J. Rihn, F. Zhang, T. Kueck, M. Alim, J. Schoggins, C.M. Rice, S.J. Wilson, and P.D. Bieniasz. 2016. Identification of Interferon-Stimulated Genes with Antiretroviral Activity. Cell Host Microbe 20:392-405.

Kaneko, N., H.H. Kuo, J. Boucau, J.R. Farmer, H. Allard-Chamard, V.S. Mahajan, A. Piechocka-Trocha, K. Lefteri, M. Osborn, J. Bals, Y.C. Bartsch, N. Bonheur, T.M. Caradonna, J. Chevalier, F. Chowdhury, T.J. Diefenbach, K. Einkauf, J. Fallon, J. Feldman, K.K. Finn, P. Garcia-Broncano, C.A. Hartana, B.M. Hauser, C. Jiang, P. Kaplonek, M. Karpell, E.C. Koscher, X. Lian, H. Liu, J. Liu, N.L. Ly, A.R. Michell, Y. Rassadkina, K. Seiger, L. Sessa, S. Shin, N. Singh, W. Sun, X. Sun, H.J. Ticheli, M.T. Waring, A.L. Zhu, G. Alter, J.Z. Li, D. Lingwood, A.G. Schmidt, M. Lichterfeld, B.D. Walker, X.G. Yu, R.F. Padera, Jr., and S. Pillai. 2020. Loss of Bcl-6-Expressing T Follicular Helper Cells and Germinal Centers in COVID-19. Cell 183:143-157.e113.

Kared, H., A.D. Redd, E.M. Bloch, T.S. Bonny, H. Sumatoh, F. Kairi, D. Carbajo, B. Abel, E.W. Newell, M.P. Bettinotti, S.E. Benner, E.U. Patel, K. Littlefield, O. Laeyendecker, S. Shoham, D. Sullivan, A. Casadevall, A. Pekosz, A. Nardin, M. Fehlings, A.A.R. Tobian, and T.C. Quinn. 2021. SARS-CoV-2-specific CD8+ T cell responses in convalescent COVID-19 individuals. The Journal of Clinical Investigation 131: 
Kuri-Cervantes, L., M.B. Pampena, W. Meng, A.M. Rosenfeld, C.A.G. Ittner, A.R. Weisman, R.S. Agyekum, D. Mathew, A.E. Baxter, L.A. Vella, O. Kuthuru, S.A. Apostolidis, L. Bershaw, J. Dougherty, A.R. Greenplate, A. Pattekar, J. Kim, N. Han, S. Gouma, M.E. Weirick, C.P. Arevalo, M.J. Bolton, E.C. Goodwin, E.M. Anderson, S.E. Hensley, T.K. Jones, N.S. Mangalmurti, E.T. Luning Prak, E.J. Wherry, N.J. Meyer, and M.R. Betts. 2020. Comprehensive mapping of immune perturbations associated with severe COVID19. Science Immunology 5:eabd7114.

Kyogoku, C., B. Smiljanovic, J.R. Grün, R. Biesen, U. Schulte-Wrede, T. Häupl, F. Hiepe, T. Alexander, A. Radbruch, and A. Grützkau. 2013. Cell-specific type I IFN signatures in autoimmunity and viral infection: what makes the difference? PLoS One 8:e83776.

Lawand, M., J. Déchanet-Merville, and M.-C. Dieu-Nosjean. 2017. Key Features of GammaDelta T-Cell Subsets in Human Diseases and Their Immunotherapeutic Implications. Frontiers in Immunology 8:

Le Bert, N., A.T. Tan, K. Kunasegaran, C.Y.L. Tham, M. Hafezi, A. Chia, M.H.Y. Chng, M. Lin, N. Tan, M. Linster, W.N. Chia, M.I.C. Chen, L.-F. Wang, E.E. Ooi, S. Kalimuddin, P.A. Tambyah, J.G.-H. Low, Y.-J. Tan, and A. Bertoletti. 2020. SARS-CoV-2-specific T cell immunity in cases of COVID-19 and SARS, and uninfected controls. Nature 584:457-462.

Le Bon, A., G. Schiavoni, G. D'Agostino, I. Gresser, F. Belardelli, and D.F. Tough. 2001. Type i interferons potently enhance humoral immunity and can promote isotype switching by stimulating dendritic cells in vivo. Immunity 14:461-470.

Lederer, K., D. Castaño, D. Gómez Atria, T.H. Oguin, 3rd, S. Wang, T.B. Manzoni, H. Muramatsu, M.J. Hogan, F. Amanat, P. Cherubin, K.A. Lundgreen, Y.K. Tam, S.H.Y. Fan, L.C. Eisenlohr, I. Maillard, D. Weissman, P. Bates, F. Krammer, G.D. Sempowski, N. Pardi, and M. Locci. 2020. SARS-CoV-2 mRNA Vaccines Foster Potent AntigenSpecific Germinal Center Responses Associated with Neutralizing Antibody Generation. Immunity 53:1281-1295.e1285.

Lester, S.N., and K. Li. 2014. Toll-like receptors in antiviral innate immunity. J Mol Biol 426:1246-1264.

Liberzon, A., C. Birger, H. Thorvaldsdóttir, M. Ghandi, J.P. Mesirov, and P. Tamayo. 2015. The Molecular Signatures Database (MSigDB) hallmark gene set collection. Cell Syst 1:417425.

Liu, C., A.J. Martins, W.W. Lau, N. Rachmaninoff, J. Chen, L. Imberti, D. Mostaghimi, D.L. Fink, P.D. Burbelo, K. Dobbs, O.M. Delmonte, N. Bansal, L. Failla, A. Sottini, E. Quiros-Roldan, K.L. Han, B.A. Sellers, F. Cheung, R. Sparks, T.W. Chun, S. Moir, M.S. Lionakis, C. Rossi, H.C. Su, D.B. Kuhns, J.I. Cohen, L.D. Notarangelo, and J.S. Tsang. 2021. Time-resolved systems immunology reveals a late juncture linked to fatal COVID19. Cell 184:1836-1857.e1822.

Liu, S.-Y., D.J. Sanchez, R. Aliyari, S. Lu, and G. Cheng. 2012. Systematic identification of type I and type II interferon-induced antiviral factors. Proceedings of the National Academy of Sciences 109:4239-4244.

Macpherson, A.J., K.D. McCoy, F.E. Johansen, and P. Brandtzaeg. 2008. The immune geography of IgA induction and function. Mucosal Immunology 1:11-22.

Major, J., S. Crotta, M. Llorian, T.M. McCabe, H.H. Gad, S.L. Priestnall, R. Hartmann, and A. Wack. 2020. Type I and III interferons disrupt lung epithelial repair during recovery from viral infection. Science 369:712. 
Malmgaard, L. 2004. Induction and regulation of IFNs during viral infections. J Interferon Cytokine Res 24:439-454.

Mathew, D., J.R. Giles, A.E. Baxter, D.A. Oldridge, A.R. Greenplate, J.E. Wu, C. Alanio, L. Kuri-Cervantes, M.B. Pampena, K. D’Andrea, S. Manne, Z. Chen, Y.J. Huang, J.P. Reilly, A.R. Weisman, C.A.G. Ittner, O. Kuthuru, J. Dougherty, K. Nzingha, N. Han, J. Kim, A. Pattekar, E.C. Goodwin, E.M. Anderson, M.E. Weirick, S. Gouma, C.P. Arevalo, M.J. Bolton, F. Chen, S.F. Lacey, H. Ramage, S. Cherry, S.E. Hensley, S.A. Apostolidis, A.C. Huang, L.A. Vella, M.R. Betts, N.J. Meyer, and E.J. Wherry. 2020. Deep immune profiling of COVID-19 patients reveals distinct immunotypes with therapeutic implications. Science 369:eabc8511.

McInnes, L., and J. Healy. 2018. UMAP: Uniform Manifold Approximation and Projection for Dimension Reduction. ArXiv abs/1802.03426:

McMahan, K., J. Yu, N.B. Mercado, C. Loos, L.H. Tostanoski, A. Chandrashekar, J. Liu, L. Peter, C. Atyeo, A. Zhu, E.A. Bondzie, G. Dagotto, M.S. Gebre, C. Jacob-Dolan, Z. Li, F. Nampanya, S. Patel, L. Pessaint, A. Van Ry, K. Blade, J. Yalley-Ogunro, M. Cabus, R. Brown, A. Cook, E. Teow, H. Andersen, M.G. Lewis, D.A. Lauffenburger, G. Alter, and D.H. Barouch. 2021. Correlates of protection against SARS-CoV-2 in rhesus macaques. Nature 590:630-634.

Meckiff, B.J., C. Ramírez-Suástegui, V. Fajardo, S.J. Chee, A. Kusnadi, H. Simon, S. Eschweiler, A. Grifoni, E. Pelosi, D. Weiskopf, A. Sette, F. Ay, G. Seumois, C.H. Ottensmeier, and P. Vijayanand. 2020. Imbalance of Regulatory and Cytotoxic SARSCoV-2-Reactive CD4(+) T Cells in COVID-19. Cell 183:1340-1353.e1316.

Melsted, P., A.S. Booeshaghi, L. Liu, F. Gao, L. Lu, K.H. Min, E. da Veiga Beltrame, K.E. Hjörleifsson, J. Gehring, and L. Pachter. 2021. Modular, efficient and constant-memory single-cell RNA-seq preprocessing. Nature Biotechnology

Merad, M., and J.C. Martin. 2020. Pathological inflammation in patients with COVID-19: a key role for monocytes and macrophages. Nature Reviews Immunology 20:355-362.

Mimitou, E.P., A. Cheng, A. Montalbano, S. Hao, M. Stoeckius, M. Legut, T. Roush, A. Herrera, E. Papalexi, Z. Ouyang, R. Satija, N.E. Sanjana, S.B. Koralov, and P. Smibert. 2019. Multiplexed detection of proteins, transcriptomes, clonotypes and CRISPR perturbations in single cells. Nature Methods 16:409-412.

Mor, M., M. Werbner, J. Alter, M. Safra, E. Chomsky, J.C. Lee, S. Hada-Neeman, K. Polonsky, C.J. Nowell, A.E. Clark, A. Roitburd-Berman, N. Ben-Shalom, M. Navon, D. Rafael, H. Sharim, E. Kiner, E.R. Griffis, J.M. Gershoni, O. Kobiler, S.L. Leibel, O. Zimhony, A.F. Carlin, G. Yaari, M. Dessau, M. Gal-Tanamy, D. Hagin, B.A. Croker, and N.T. Freund. 2021. Multi-clonal SARS-CoV-2 neutralization by antibodies isolated from severe COVID-19 convalescent donors. PLoS Pathog 17:e1009165.

Murira, A., and A. Lamarre. 2016. Type-I Interferon Responses: From Friend to Foe in the Battle against Chronic Viral Infection. Frontiers in Immunology 7:

Nielsen, S.C.A., F. Yang, K.J.L. Jackson, R.A. Hoh, K. Röltgen, G.H. Jean, B.A. Stevens, J.-Y. Lee, A. Rustagi, A.J. Rogers, A.E. Powell, M. Hunter, J. Najeeb, A.R. Otrelo-Cardoso, K.E. Yost, B. Daniel, K.C. Nadeau, H.Y. Chang, A.T. Satpathy, T.S. Jardetzky, P.S. Kim, T.T. Wang, B.A. Pinsky, C.A. Blish, and S.D. Boyd. 2020. Human B Cell Clonal Expansion and Convergent Antibody Responses to SARS-CoV-2. Cell Host \& Microbe 28:516-525.e515. 
Noval, M.G., M.E. Kaczmarek, A. Koide, B.A. Rodriguez-Rodriguez, P. Louie, T. Tada, T. Hattori, T. Panchenko, L.A. Romero, K.W. Teng, A. Bazley, M. de Vries, M.I. Samanovic, J.N. Weiser, I. Aifantis, J. Cangiarella, M.J. Mulligan, L. Desvignes, M. Dittmann, N.R. Landau, M. Aguero-Rosenfeld, S. Koide, and K.A. Stapleford. 2021. Antibody isotype diversity against SARS-CoV-2 is associated with differential serum neutralization capacities. Sci Rep 11:5538.

Odak, I., J. Barros-Martins, B. Bošnjak, K. Stahl, S. David, O. Wiesner, M. Busch, M.M. Hoeper, I. Pink, T. Welte, M. Cornberg, M. Stoll, L. Goudeva, R. Blasczyk, A. Ganser, I. Prinz, R. Förster, C. Koenecke, and C.R. Schultze-Florey. 2020. Reappearance of effector $\mathrm{T}$ cells is associated with recovery from COVID-19. EBioMedicine 57:102885.

Oja, A.E., A. Saris, C.A. Ghandour, N.A.M. Kragten, B.M. Hogema, E.J. Nossent, L.M.A. Heunks, S. Cuvalay, E. Slot, F. Linty, F.H. Swaneveld, H. Vrielink, G. Vidarsson, T. Rispens, E. van der Schoot, R.A.W. van Lier, A. Ten Brinke, and P. Hombrink. 2020. Divergent SARS-CoV-2-specific T- and B-cell responses in severe but not mild COVID19 patients. Eur J Immunol 50:1998-2012.

Parameswaran, P., Y. Liu, K.M. Roskin, K.K. Jackson, V.P. Dixit, J.Y. Lee, K.L. Artiles, S. Zompi, M.J. Vargas, B.B. Simen, B. Hanczaruk, K.R. McGowan, M.A. Tariq, N. Pourmand, D. Koller, A. Balmaseda, S.D. Boyd, E. Harris, and A.Z. Fire. 2013. Convergent antibody signatures in human dengue. Cell Host Microbe 13:691-700.

Planas, D., T. Bruel, L. Grzelak, F. Guivel-Benhassine, I. Staropoli, F. Porrot, C. Planchais, J. Buchrieser, M.M. Rajah, E. Bishop, M. Albert, F. Donati, M. Prot, S. Behillil, V. Enouf, M. Maquart, M. Smati-Lafarge, E. Varon, F. Schortgen, L. Yahyaoui, M. Gonzalez, J. De Sèze, H. Péré, D. Veyer, A. Sève, E. Simon-Lorière, S. Fafi-Kremer, K. Stefic, H. Mouquet, L. Hocqueloux, S. van der Werf, T. Prazuck, and O. Schwartz. 2021. Sensitivity of infectious SARS-CoV-2 B.1.1.7 and B.1.351 variants to neutralizing antibodies. Nature Medicine

Premkumar, L., B. Segovia-Chumbez, R. Jadi, D.R. Martinez, R. Raut, A.J. Markmann, C. Cornaby, L. Bartelt, S. Weiss, Y. Park, C.E. Edwards, E. Weimer, E.M. Scherer, N. Rouphael, S. Edupuganti, D. Weiskopf, L.V. Tse, Y.J. Hou, D. Margolis, A. Sette, M.H. Collins, J. Schmitz, R.S. Baric, and A.M. de Silva. 2020. The receptor-binding domain of the viral spike protein is an immunodominant and highly specific target of antibodies in SARS-CoV-2 patients. Science Immunology 5:eabc8413.

R Core Team. 2018. R: A Language and Environment for Statistical Computing. In R Foundation for Statistical Computing, Vienna, Austria.

Redd, A.D., A. Nardin, H. Kared, E.M. Bloch, A. Pekosz, O. Laeyendecker, B. Abel, M. Fehlings, T.C. Quinn, and A.A.R. Tobian. 2021. CD8+ T cell responses in COVID-19 convalescent individuals target conserved epitopes from multiple prominent SARS-CoV2 circulating variants. Open Forum Infectious Diseases

Robbiani, D.F., C. Gaebler, F. Muecksch, J.C.C. Lorenzi, Z. Wang, A. Cho, M. Agudelo, C.O. Barnes, A. Gazumyan, S. Finkin, T. Hägglöf, T.Y. Oliveira, C. Viant, A. Hurley, H.-H. Hoffmann, K.G. Millard, R.G. Kost, M. Cipolla, K. Gordon, F. Bianchini, S.T. Chen, V. Ramos, R. Patel, J. Dizon, I. Shimeliovich, P. Mendoza, H. Hartweger, L. Nogueira, M. Pack, J. Horowitz, F. Schmidt, Y. Weisblum, E. Michailidis, A.W. Ashbrook, E. Waltari, J.E. Pak, K.E. Huey-Tubman, N. Koranda, P.R. Hoffman, A.P. West, C.M. Rice, T. Hatziioannou, P.J. Bjorkman, P.D. Bieniasz, M. Caskey, and M.C. Nussenzweig. 2020. 
Convergent antibody responses to SARS-CoV-2 in convalescent individuals. Nature 584:437-442.

Rodríguez-Bayona, B., A. Ramos-Amaya, R. López-Blanco, A. Campos-Caro, and J.A. Brieva. 2013. STAT-3 activation by differential cytokines is critical for human in vivo-generated plasma cell survival and Ig secretion. J Immunol 191:4996-5004.

Rönnblom, L., and D. Leonard. 2019. Interferon pathway in SLE: one key to unlocking the mystery of the disease. Lupus Science \&amp; amp; Medicine 6:e000270.

Sabbaghi, A., S.M. Miri, M. Keshavarz, M. Mahooti, A. Zebardast, and A. Ghaemi. 2020. Role of $\gamma \delta \mathrm{T}$ cells in controlling viral infections with a focus on influenza virus: implications for designing novel therapeutic approaches. Virology Journal 17:174.

Satarker, S., and M. Nampoothiri. 2020. Structural Proteins in Severe Acute Respiratory Syndrome Coronavirus-2. Arch Med Res 51:482-491.

Sauer, K., and T. Harris. 2020. An Effective COVID-19 Vaccine Needs to Engage T Cells. Front Immunol 11:581807.

Scagnolari, C., A. Pierangeli, F. Frasca, C. Bitossi, A. Viscido, G. Oliveto, M. Scordio, L. Mazzuti, D. Di Carlo, M. Gentile, A. Solimini, G. Ceccarelli, F. Pugliese, C.M. Mastroianni, G. d'Ettorre, O. Turriziani, and G. Antonelli. 2021. Differential induction of type I and III interferon genes in the upper respiratory tract of patients with coronavirus disease 2019 (COVID-19). Virus Research 295:198283.

Sherina, N., A. Piralla, L. Du, H. Wan, M. Kumagai-Braesch, J. Andréll, S. Braesch-Andersen, I. Cassaniti, E. Percivalle, A. Sarasini, F. Bergami, R. Di Martino, M. Colaneri, M. Vecchia, M. Sambo, V. Zuccaro, R. Bruno, M. Sachs, T. Oggionni, F. Meloni, H. Abolhassani, F. Bertoglio, M. Schubert, M. Byrne-Steele, J. Han, M. Hust, Y. Xue, L. Hammarström, F. Baldanti, H. Marcotte, and Q. Pan-Hammarström. 2021. Persistence of SARS-CoV-2-specific B and T cell responses in convalescent COVID-19 patients 68 months after the infection. Med 2:281-295.e284.

Singh, R., M. Bajpai, P. Yadav, A.K. Maheshwari, S. Kumar, S. Agrawal, J. Kumar, I. Md, J.S. Mars, G. Ramakrishna, S.K. Sarin, and N. Trehanpati. 2020. Sustained expression of inflammatory monocytes and activated T cells in COVID-19 patients and recovered convalescent plasma donors. medRxiv 2020.2011.2017.20233668.

Soni, C., O.A. Perez, W.N. Voss, J.N. Pucella, L. Serpas, J. Mehl, K.L. Ching, J. Goike, G. Georgiou, G.C. Ippolito, V. Sisirak, and B. Reizis. 2020. Plasmacytoid Dendritic Cells and Type I Interferon Promote Extrafollicular B Cell Responses to Extracellular SelfDNA. Immunity 52:1022-1038.e1027.

Stebegg, M., S.D. Kumar, A. Silva-Cayetano, V.R. Fonseca, M.A. Linterman, and L. Graca. 2018. Regulation of the Germinal Center Response. Frontiers in Immunology 9:

Sterlin, D., A. Mathian, M. Miyara, A. Mohr, F. Anna, L. Claër, P. Quentric, J. Fadlallah, H. Devilliers, P. Ghillani, C. Gunn, R. Hockett, S. Mudumba, A. Guihot, C.-E. Luyt, J. Mayaux, A. Beurton, S. Fourati, T. Bruel, O. Schwartz, J.-M. Lacorte, H. Yssel, C. Parizot, K. Dorgham, P. Charneau, Z. Amoura, and G. Gorochov. 2021. IgA dominates the early neutralizing antibody response to SARS-CoV-2. Science Translational Medicine 13:eabd2223.

Stoeckius, M., C. Hafemeister, W. Stephenson, B. Houck-Loomis, P.K. Chattopadhyay, H. Swerdlow, R. Satija, and P. Smibert. 2017. Simultaneous epitope and transcriptome measurement in single cells. Nat Methods 14:865-868. 
Stoeckius, M., S. Zheng, B. Houck-Loomis, S. Hao, B.Z. Yeung, W.M. Mauck, 3rd, P. Smibert, and R. Satija. 2018. Cell Hashing with barcoded antibodies enables multiplexing and doublet detection for single cell genomics. Genome Biol 19:224.

Stuart, T., A. Butler, P. Hoffman, C. Hafemeister, E. Papalexi, W.M. Mauck, 3rd, Y. Hao, M. Stoeckius, P. Smibert, and R. Satija. 2019. Comprehensive Integration of Single-Cell Data. Cell 177:1888-1902 e1821.

Sun, B., and Y. Zhang. 2014. Overview of orchestration of CD4+ T cell subsets in immune responses. Adv Exp Med Biol 841:1-13.

Swain, S.L., K.K. McKinstry, and T.M. Strutt. 2012. Expanding roles for CD4+ T cells in immunity to viruses. Nature Reviews Immunology 12:136-148.

Swanson, C.L., T.J. Wilson, P. Strauch, M. Colonna, R. Pelanda, and R.M. Torres. 2010. Type I IFN enhances follicular B cell contribution to the T cell-independent antibody response. $J$ Exp Med 207:1485-1500.

Tai, W., L. He, X. Zhang, J. Pu, D. Voronin, S. Jiang, Y. Zhou, and L. Du. 2020. Characterization of the receptor-binding domain (RBD) of 2019 novel coronavirus: implication for development of RBD protein as a viral attachment inhibitor and vaccine. Cellular \& Molecular Immunology 17:613-620.

Tailor, P., T. Tamura, H.J. Kong, T. Kubota, M. Kubota, P. Borghi, L. Gabriele, and K. Ozato. 2007. The feedback phase of type I interferon induction in dendritic cells requires interferon regulatory factor 8. Immunity 27:228-239.

Takeuchi, A., and T. Saito. 2017. CD4 CTL, a Cytotoxic Subset of CD4(+) T Cells, Their Differentiation and Function. Frontiers in immunology 8:194-194.

Teijaro, J.R. 2016. Type I interferons in viral control and immune regulation. Curr Opin Virol 16:31-40.

Thewissen, M., V. Somers, N. Hellings, J. Fraussen, J. Damoiseaux, and P. Stinissen. 2007. CD4+CD28null T cells in autoimmune disease: pathogenic features and decreased susceptibility to immunoregulation. J Immunol 179:6514-6523.

Thompson, M.G., J.L. Burgess, A.L. Naleway, H.L. Tyner, S.K. Yoon, J. Meece, L.E.W. Olsho, A.J. Caban-Martinez, A. Fowlkes, K. Lutrick, J.L. Kuntz, K. Dunnigan, M.J. Odean, K.T. Hegmann, E. Stefanski, L.J. Edwards, N. Schaefer-Solle, L. Grant, K. Ellingson, H.C. Groom, T. Zunie, M.S. Thiese, L. Ivacic, M.G. Wesley, J.M. Lamberte, X. Sun, M.E. Smith, A.L. Phillips, K.D. Groover, Y.M. Yoo, J. Gerald, R.T. Brown, M.K. Herring, G. Joseph, S. Beitel, T.C. Morrill, J. Mak, P. Rivers, K.M. Harris, D.R. Hunt, M.L. Arvay, P. Kutty, A.M. Fry, and M. Gaglani. 2021. Interim Estimates of Vaccine Effectiveness of BNT162b2 and mRNA-1273 COVID-19 Vaccines in Preventing SARS-CoV-2 Infection Among Health Care Personnel, First Responders, and Other Essential and Frontline Workers - Eight U.S. Locations, December 2020-March 2021. MMWR Morb Mortal Wkly Rep 70:495-500.

Vella, L.A., M. Buggert, S. Manne, R.S. Herati, I. Sayin, L. Kuri-Cervantes, I. Bukh Brody, K.C. O'Boyle, H. Kaprielian, J.R. Giles, S. Nguyen, A. Muselman, J.P. Antel, A. Bar-Or, M.E. Johnson, D.H. Canaday, A. Naji, V.V. Ganusov, T.M. Laufer, A.D. Wells, Y. Dori, M.G. Itkin, M.R. Betts, and E.J. Wherry. 2019. T follicular helper cells in human efferent lymph retain lymphoid characteristics. J Clin Invest 129:3185-3200.

Vogel, A.B., I. Kanevsky, Y. Che, K.A. Swanson, A. Muik, M. Vormehr, L.M. Kranz, K.C. Walzer, S. Hein, A. Güler, J. Loschko, M.S. Maddur, K. Tompkins, J. Cole, B.G. Lui, T. Ziegenhals, A. Plaschke, D. Eisel, S.C. Dany, S. Fesser, S. Erbar, F. Bates, D. Schneider, 
B. Jesionek, B. Sänger, A.-K. Wallisch, Y. Feuchter, H. Junginger, S.A. Krumm, A.P. Heinen, P. Adams-Quack, J. Schlereth, C. Kröner, S. Hall-Ursone, K. Brasky, M.C. Griffor, S. Han, J.A. Lees, E.H. Mashalidis, P.V. Sahasrabudhe, C.Y. Tan, D. Pavliakova, G. Singh, C. Fontes-Garfias, M. Pride, I.L. Scully, T. Ciolino, J. Obregon, M. Gazi, R. Carrion, K.J. Alfson, W.V. Kalina, D. Kaushal, P.-Y. Shi, T. Klamp, C. Rosenbaum, A.N. Kuhn, Ö. Türeci, P.R. Dormitzer, K.U. Jansen, and U. Sahin. 2020. A prefusion SARS-CoV-2 spike RNA vaccine is highly immunogenic and prevents lung infection in non-human primates. bioRxiv 2020.2009.2008.280818.

Wang, X., X. Guo, Q. Xin, Y. Pan, Y. Hu, J. Li, Y. Chu, Y. Feng, and Q. Wang. 2020. Neutralizing Antibody Responses to Severe Acute Respiratory Syndrome Coronavirus 2 in Coronavirus Disease 2019 Inpatients and Convalescent Patients. Clin Infect Dis 71:2688-2694.

Wang, Z., F. Schmidt, Y. Weisblum, F. Muecksch, C.O. Barnes, S. Finkin, D. SchaeferBabajew, M. Cipolla, C. Gaebler, J.A. Lieberman, T.Y. Oliveira, Z. Yang, M.E. Abernathy, K.E. Huey-Tubman, A. Hurley, M. Turroja, K.A. West, K. Gordon, K.G. Millard, V. Ramos, J. Da Silva, J. Xu, R.A. Colbert, R. Patel, J. Dizon, C. UnsonO’Brien, I. Shimeliovich, A. Gazumyan, M. Caskey, P.J. Bjorkman, R. Casellas, T. Hatziioannou, P.D. Bieniasz, and M.C. Nussenzweig. 2021. mRNA vaccine-elicited antibodies to SARS-CoV-2 and circulating variants. Nature

WHO Working Group on the Clinical Characterisation and Management of COVID-19 infection. 2020. A minimal common outcome measure set for COVID-19 clinical research. Lancet Infect Dis 20:e192-e197.

Wilk, A.J., A. Rustagi, N.Q. Zhao, J. Roque, G.J. Martínez-Colón, J.L. McKechnie, G.T. Ivison, T. Ranganath, R. Vergara, T. Hollis, L.J. Simpson, P. Grant, A. Subramanian, A.J. Rogers, and C.A. Blish. 2020. A single-cell atlas of the peripheral immune response in patients with severe COVID-19. Nature Medicine 26:1070-1076.

Wu, J., B. Liang, C. Chen, H. Wang, Y. Fang, S. Shen, X. Yang, B. Wang, L. Chen, Q. Chen, Y. Wu, J. Liu, X. Yang, W. Li, B. Zhu, W. Zhou, H. Wang, S. Li, S. Lu, D. Liu, H. Li, A. Krawczyk, M. Lu, D. Yang, F. Deng, U. Dittmer, M. Trilling, and X. Zheng. 2021. SARS-CoV-2 infection induces sustained humoral immune responses in convalescent patients following symptomatic COVID-19. Nature Communications 12:1813.

Wu, W., and J.P. Metcalf. 2020. The Role of Type I IFNs in Influenza: Antiviral Superheroes or Immunopathogenic Villains? Journal of Innate Immunity 12:437-447.

Xagorari, A., and K. Chlichlia. 2008. Toll-like receptors and viruses: induction of innate antiviral immune responses. Open Microbiol J 2:49-59.

Xu, G., F. Qi, H. Li, Q. Yang, H. Wang, X. Wang, X. Liu, J. Zhao, X. Liao, Y. Liu, L. Liu, S. Zhang, and Z. Zhang. 2020. The differential immune responses to COVID-19 in peripheral and lung revealed by single-cell RNA sequencing. Cell Discovery 6:73.

Ye, J., N. Ma, T.L. Madden, and J.M. Ostell. 2013. IgBLAST: an immunoglobulin variable domain sequence analysis tool. Nucleic Acids Research 41:W34-W40.

Yu, K., J. He, Y. Wu, B. Xie, X. Liu, B. Wei, H. Zhou, B. Lin, Z. Zuo, W. Wen, W. Xu, B. Zou, L. Wei, X. Huang, and P. Zhou. 2020. Dysregulated adaptive immune response contributes to severe COVID-19. Cell Research 30:814-816.

Zhang, J.-Y., X.-M. Wang, X. Xing, Z. Xu, C. Zhang, J.-W. Song, X. Fan, P. Xia, J.-L. Fu, S.-Y. Wang, R.-N. Xu, X.-P. Dai, L. Shi, L. Huang, T.-J. Jiang, M. Shi, Y. Zhang, A. Zumla, 
medRxiv preprint doi: https://doi.org/10.1101/2021.04.20.21255677; this version posted August 23, 2021. The copyright holder for this preprint

(which was not certified by peer review) is the author/funder, who has granted medRxiv a license to display the preprint in perpetuity.

All rights reserved. No reuse allowed without permission.

M. Maeurer, F. Bai, and F.-S. Wang. 2020. Single-cell landscape of immunological responses in patients with COVID-19. Nature Immunology 21:1107-1118.

Zhang, Q., B. Ju, J. Ge, J.F.-W. Chan, L. Cheng, R. Wang, W. Huang, M. Fang, P. Chen, B. Zhou, S. Song, S. Shan, B. Yan, S. Zhang, X. Ge, J. Yu, J. Zhao, H. Wang, L. Liu, Q. Lv, L. Fu, X. Shi, K.Y. Yuen, L. Liu, Y. Wang, Z. Chen, L. Zhang, X. Wang, and Z. Zhang. 2021. Potent and protective IGHV3-53/3-66 public antibodies and their shared escape mutant on the spike of SARS-CoV-2. Nature Communications 12:4210.

Zheng, J., Y. Wang, K. Li, D.K. Meyerholz, C. Allamargot, and S. Perlman. 2021. Severe Acute Respiratory Syndrome Coronavirus 2-Induced Immune Activation and Death of Monocyte-Derived Human Macrophages and Dendritic Cells. J Infect Dis 223:785-795.

Zhou, Z., L. Ren, L. Zhang, J. Zhong, Y. Xiao, Z. Jia, L. Guo, J. Yang, C. Wang, S. Jiang, D. Yang, G. Zhang, H. Li, F. Chen, Y. Xu, M. Chen, Z. Gao, J. Yang, J. Dong, B. Liu, X. Zhang, W. Wang, K. He, Q. Jin, M. Li, and J. Wang. 2020. Heightened Innate Immune Responses in the Respiratory Tract of COVID-19 Patients. Cell Host Microbe 27:883890.e882.

Zuniga, M., C. Gomes, S.E. Carsons, M.T. Bender, P. Cotzia, Q.R. Miao, D.C. Lee, and A. Rodriguez. 2021. Autoimmunity to the Lung Protective Phospholipid-Binding Protein Annexin A2 Predicts Mortality Among Hospitalized COVID-19 Patients. medRxiv 2020.2012.2028.20248807.

Zuo, J., A.C. Dowell, H. Pearce, K. Verma, H.M. Long, J. Begum, F. Aiano, Z. AminChowdhury, B. Hallis, L. Stapley, R. Borrow, E. Linley, S. Ahmad, B. Parker, A. Horsley, G. Amirthalingam, K. Brown, M.E. Ramsay, S. Ladhani, and P. Moss. 2021. Robust SARS-CoV-2-specific T cell immunity is maintained at 6 months following primary infection. Nature Immunology 
medRxiv preprint doi: https://doi.org/10.1101/2021.04.20.21255677; this version posted August 23, 2021. The copyright holder for this preprint (which was not certified by peer review) is the author/funder, who has granted medRxiv a license to display the preprint in perpetuity.

All rights reserved. No reuse allowed without permission.

\section{Supplemental Figure Legends}

\section{Supplemental Figure 1: Analysis of immune landscape in COVID-19 and in vaccinated Individuals}

a. Distribution of signal from characteristic ADTs. UMAP representation of all immune subsets can be found in Fig. 1A.

b. Significance table of p-values determined by an ANOVA of linear mixed models and post-hoc pairwise comparison of estimated marginal means in Plasmablasts and Naïve CD8 T cells.

c,d. Graphs of cell percentages of NEAT $1{ }^{\text {hi }}$ Monocytes and Proliferating T cells that exhibited significant differences between COVID-19-naïve donors and healthy volunteers before receiving the BNT162b2 mRNA vaccine (blue), healthy volunteers after receiving the BNT162b2 mRNA vaccine (orange), and COVID-19 patients (red). P-values are determined by an ANOVA of linear mixed models and post-hoc pairwise comparison of estimated marginal means.

\section{Supplemental Figure 2: Expression of type I interferon pathway in M1 Macrophages}

a. Expression of $I R F 7, I R F 8$, and $L I L R B 1$ in $\mathrm{M} 1$ macrophages from $\mathrm{HC}$, Vaccine samples and COVID-19 patients.

b. Scaled and normalized expression of IFN production-associated genes in M1 macrophages based on gene ontology $(\mathrm{GO})$ gene set for type I IFN production (GO:0032606).

\section{Supplemental Figure 3: Ab titers and plasmablast responses}

a-c. SARS-CoV-2-specific Ab titers were assessed for COVID-19 patients and healthy volunteers using Multiplex Bead Binding Assay (MBBA). IgG, IgA and IgM anti-NC responses are shown in (a), anti-spike responses in (b). IgM responses to RBD are shown in (c), with $\operatorname{IgA}$ and $\mathrm{IgG}$ anti-RBD responses shown in Fig. 3.

d. Per sample PCA plot based on combined gene sets for IFN response and IFN stimulated gene signatures with the expression of four transcripts with strong correlations to PC1 indicated above.

\section{Supplemental Figure 4: Tfh response signature}

a. GSVA of Tfh responses in COVID-19 patient biospecimens and in cells from healthy volunteers.

b. Average per-sample scaled expression of genes associated with cytotoxic effector function from the gene set $\mathrm{T}$ cell mediated cytotoxicity (GO:0001913) in NK, MAIT, CD8 T effector, gdT, CD4 T activated cells. 
medRxiv preprint doi: https://doi.org/10.1101/2021.04.20.21255677; this version posted August 23, 2021. The copyright holder for this preprint (which was not certified by peer review) is the author/funder, who has granted medRxiv a license to display the preprint in perpetuity.

All rights reserved. No reuse allowed without permission.

\section{Supplemental Figure 5: Assessment of clonal T cell responses}

a,b. Evaluation of clonal responses in CD8 T eff population from COVID-19 patients (a) and HCs (b), with bar graphs showing clonal repertoire distribution among CD8 TEM and Teff cells based on TCR $\beta$ CDR3 sequences. Polyclonal cells in grey. Circos plots of frequencies of $\mathrm{V} \beta$ and $\mathrm{J} \beta$ usage are shown (bottom).

c,d. Clonal repertoire distribution among $\gamma \delta$ T cells based on TCR $\delta$ CDR3 sequence in COVID-19 patients (a) and HCs (b). Polyclonal cells in grey. Circos plots of frequencies of V $\delta$ and $\mathrm{J} \delta$ usage are shown (bottom). 


\section{Schematic 1}

Samples

Healthy controls

Cells for 5'-CITE-seq

SK $\mathrm{SK}-007 \mathrm{O}$

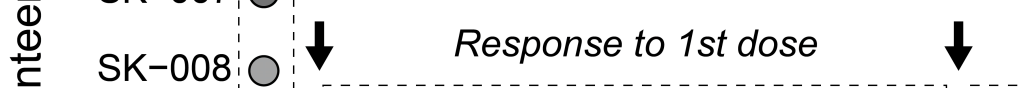

Response to 2nd dose
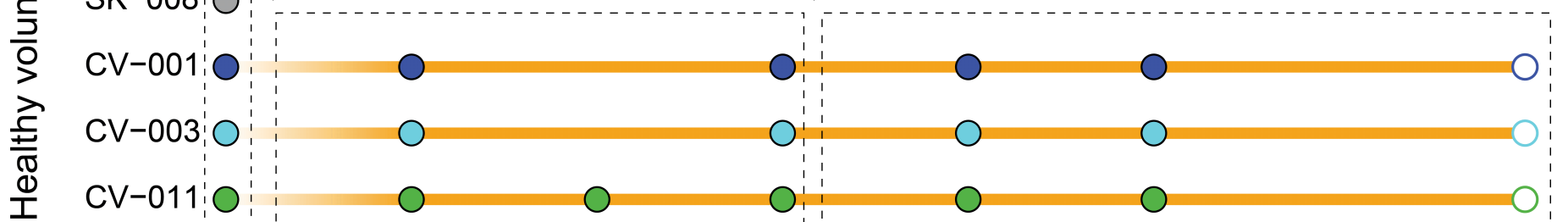

I CV-011:

(nter

Days after first immunization

$0 \quad 7$

14

21

28

35

42

35

21

28

42

49

Days post onset (DPO)

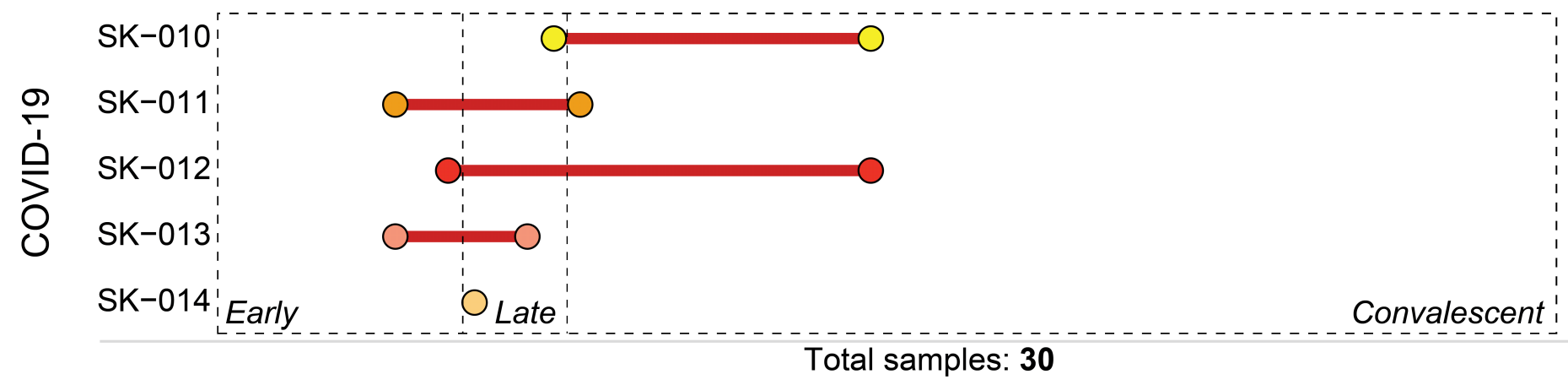

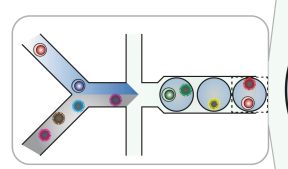

\section{5'-CITE-seq}

Transcriptome 60 Surface proteins TCRaß TCRYठ BCR

\section{Antibody Profiling}

$\lg \mathrm{M}$

$\lg \mathrm{A}$

IgG

Spike

RBD

$=$

11

Total samples: $\mathbf{3 0}$ 
A

medRxiv preprint doi: https://doi.org/10.1101/2021.04.20.21255677; this version posted August 23, 2021. The copyright holder for this preprint (which was not certified by peer review) is the author/funder, who has $\mathrm{g}$ ted medRxiv a license to display the preprint in perpetuity.

IRF7

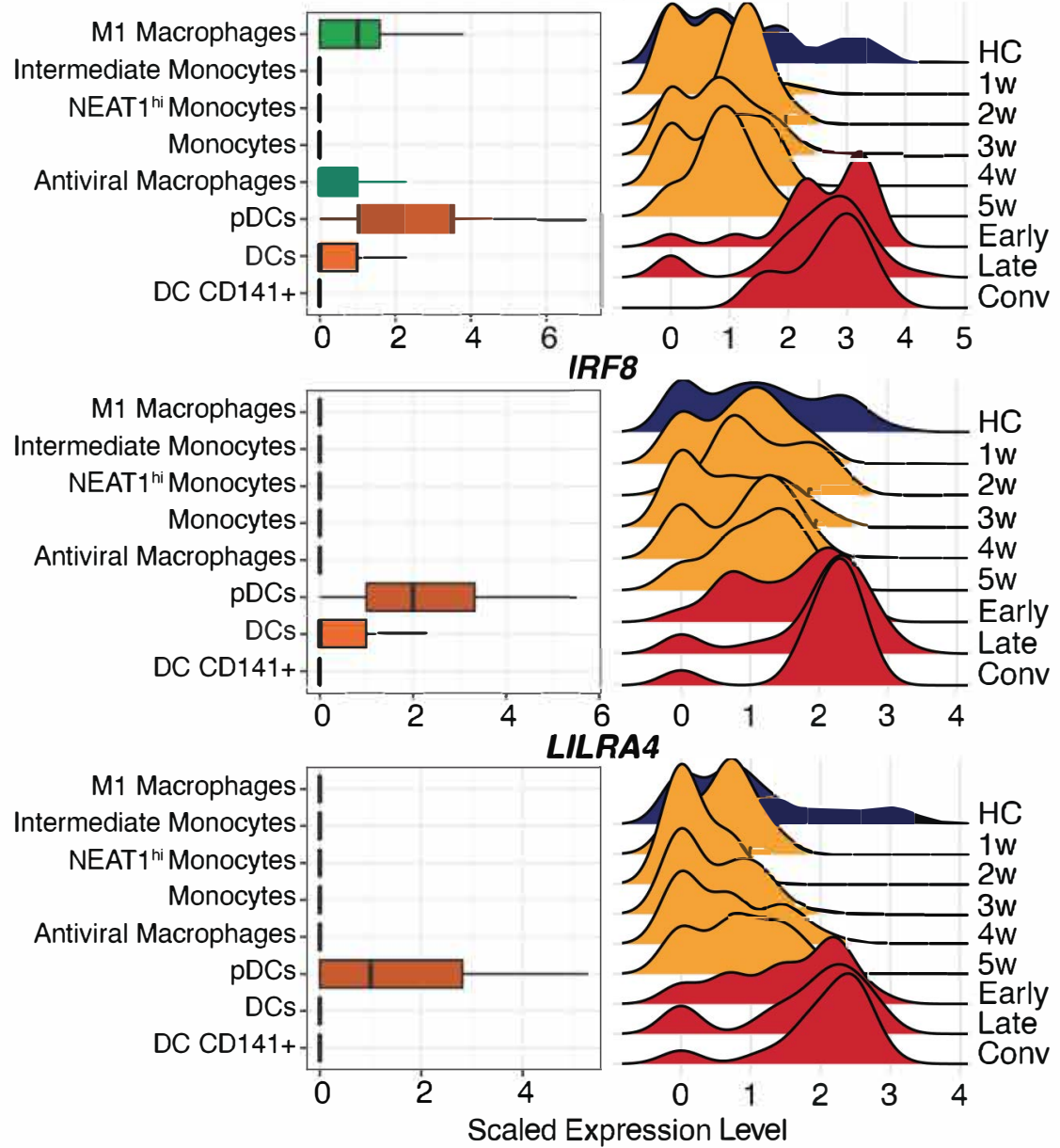

1w 2w 3w 4w 5w Early Late Conv
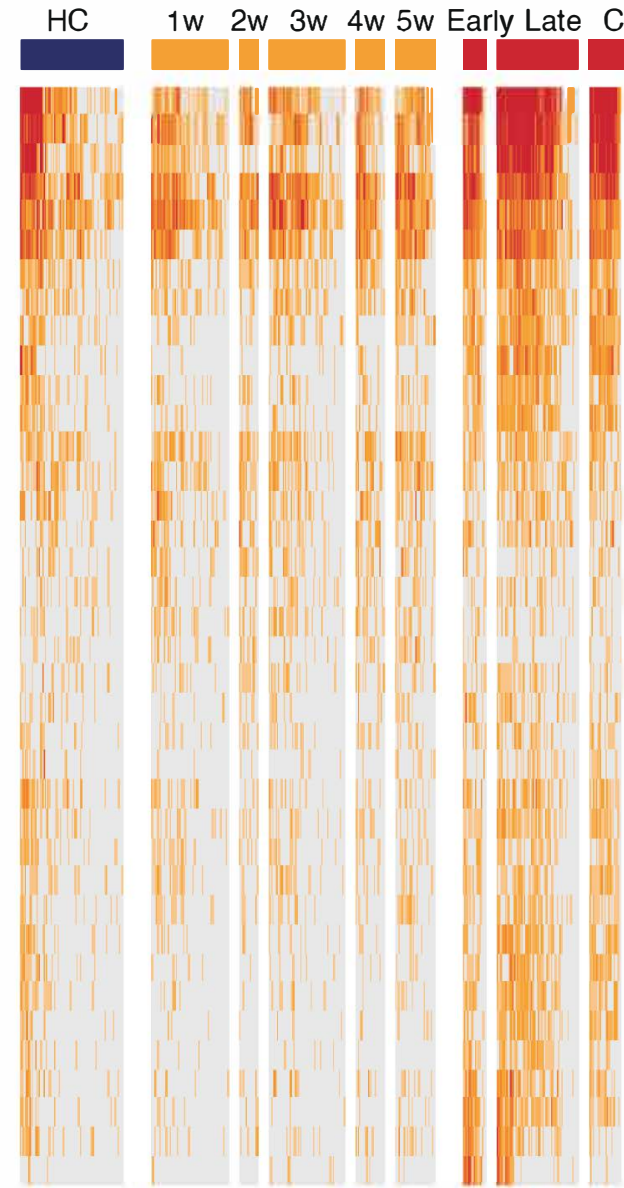

IRF7

IRF8

LILRA4

PCBP2

HMGB1

HSP90AA1

LRRFIP1

PTPRS

SYK

PYCARD

XRCC6

XRCC5

TAX1BP1

REL

DDX3X

IRF1

RELB

SETD2

DHX9

TNFAIP3

CYLD

HERC5

POLR2K

PRKDC

POLR2L

PIN1

UFD1

PQBP1

YY1

POLR2E

HSPD1

MYD88

FLOT1

LILRB1

IFI16

UBE2L6

STAT1

ISG15
Scaled

Expression

-4
-3
-2
1
0


A

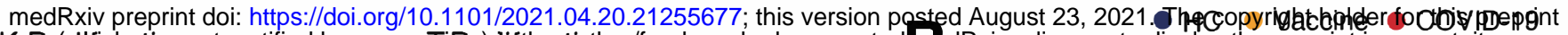

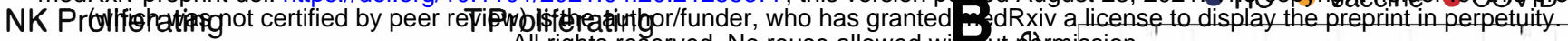

$\mathrm{HC}$ Vaccine Early Late Conv $\mathrm{HC} \quad$ Vaccine ${ }_{\text {All }}$ Eahts reserved. No reuse

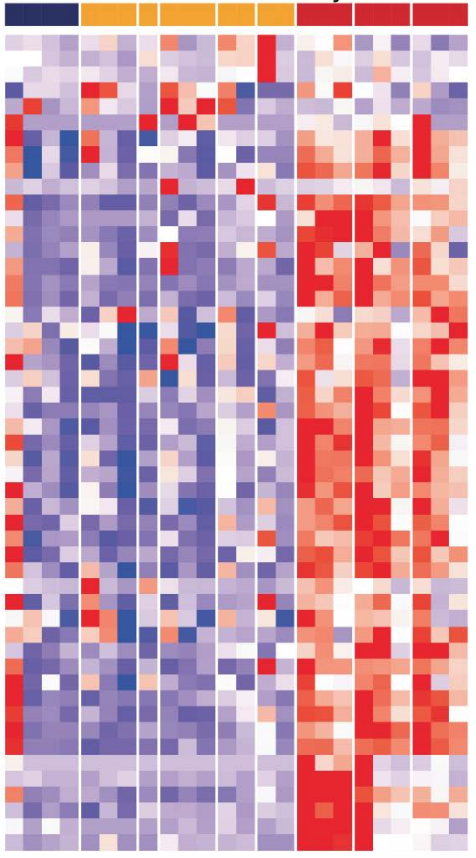

TCR $\alpha \beta$ in Conventional T cells

D

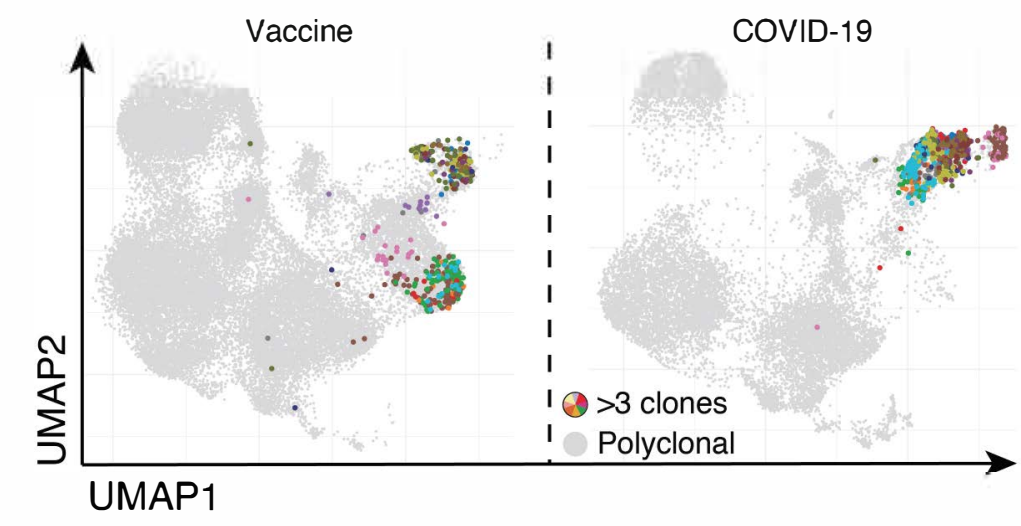

$\mathbf{F}$ 150

CV-011 (Vaccine Time Course)

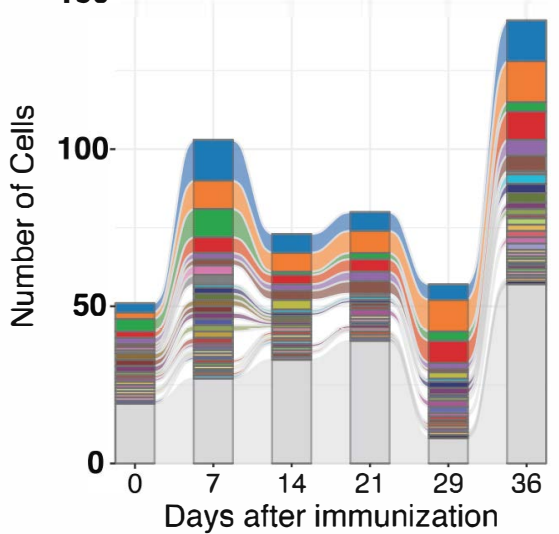

$\beta$ chain

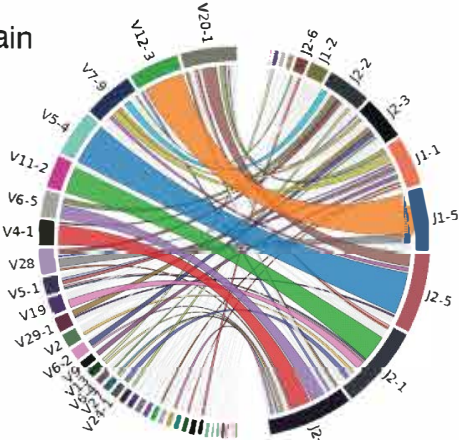

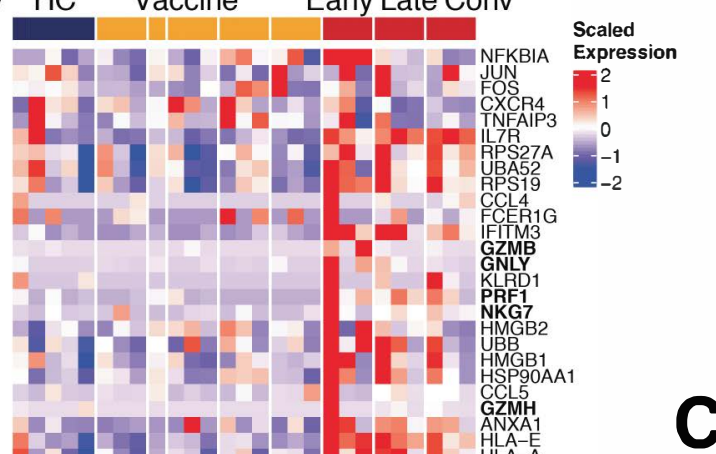

E

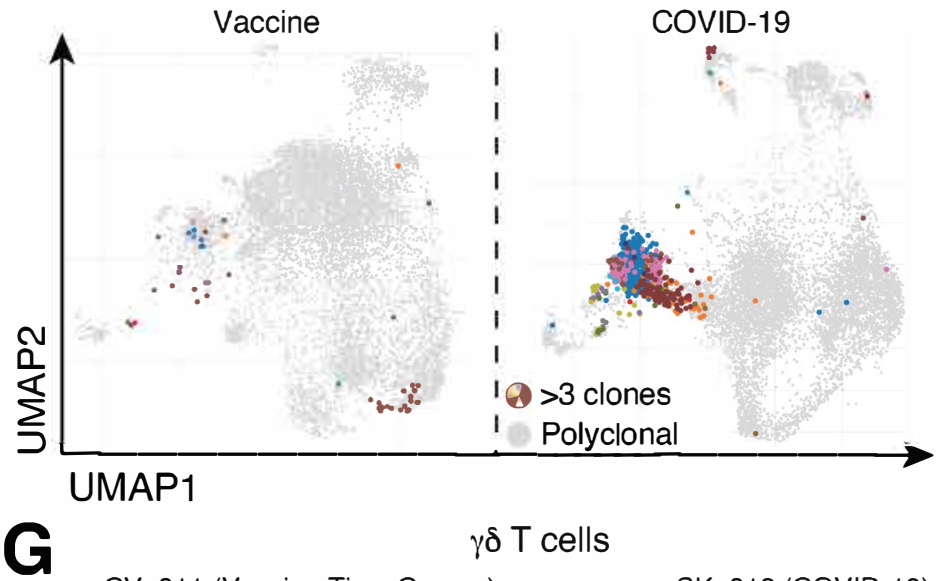

CV-011 (Vaccine Time Course)

200 -

60

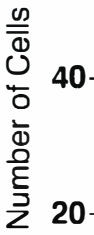
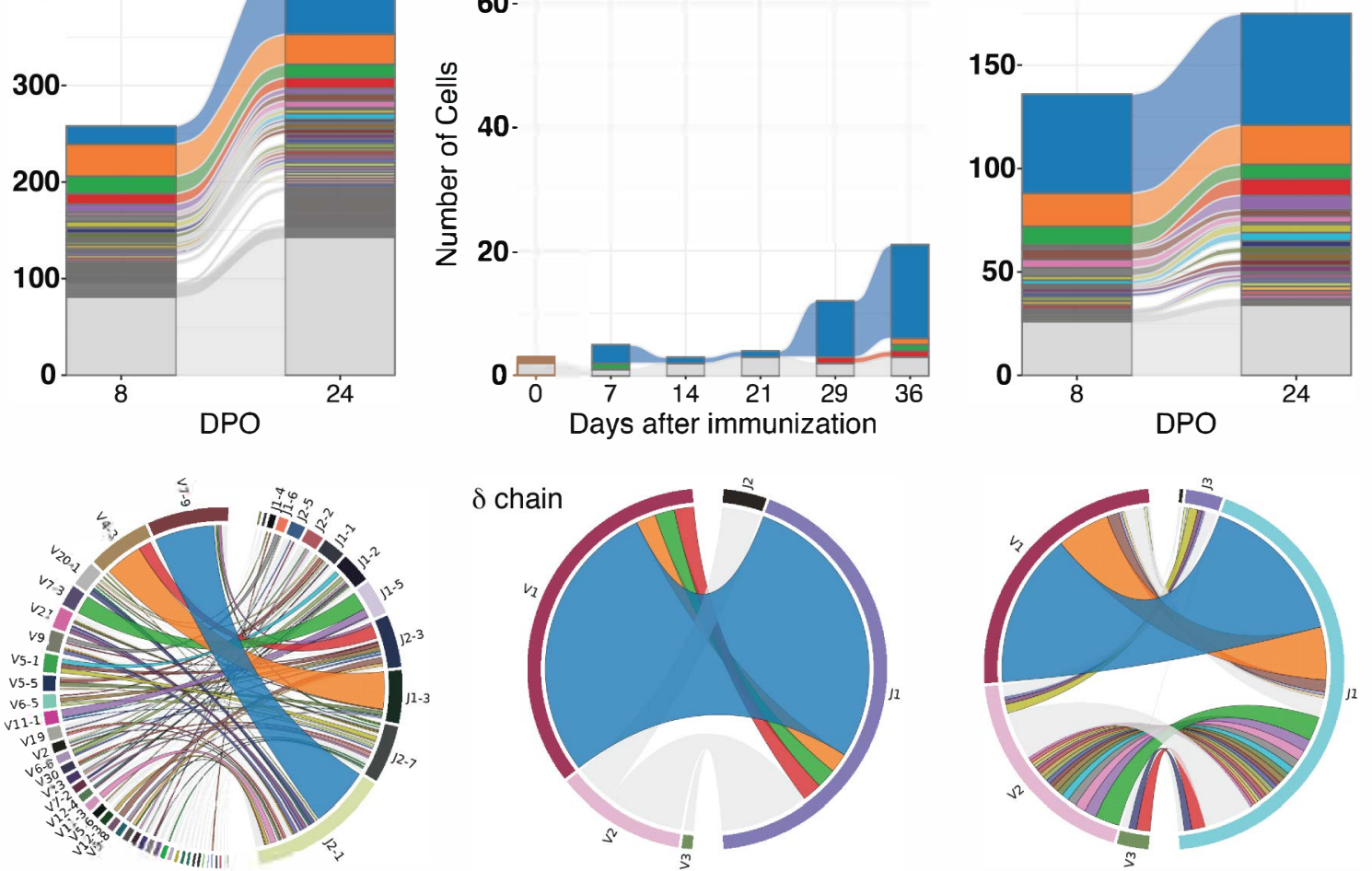